\title{
A satellite-based estimate of combustion aerosol cloud microphysical effects over the Arctic Ocean
}

\author{
Lauren M. Zamora ${ }^{1,2}$, Ralph A. Kahn ${ }^{2}$, Klaus B. Huebert ${ }^{3}$, Andreas Stohl ${ }^{4}$, and Sabine Eckhardt ${ }^{4}$ \\ ${ }^{1}$ Earth System Science Interdisciplinary Center, University of Maryland, College Park, MD, USA \\ ${ }^{2}$ NASA Goddard Space Flight Center, Greenbelt, MD, USA \\ ${ }^{3}$ Horn Point Laboratory, University of Maryland Center for Environmental Science, Cambridge, MD, USA \\ ${ }^{4}$ NILU - Norwegian Institute for Air Research, Kjeller, Norway
}

Correspondence: Lauren M. Zamora (lauren.m.zamora@nasa.gov)

Received: 23 May 2018 - Discussion started: 30 May 2018

Revised: 21 September 2018 - Accepted: 4 October 2018 - Published: 18 October 2018

\begin{abstract}
Climate predictions for the rapidly changing Arctic are highly uncertain, largely due to a poor understanding of the processes driving cloud properties. In particular, cloud fraction $(\mathrm{CF})$ and cloud phase $(\mathrm{CP})$ have major impacts on energy budgets, but are poorly represented in most models, often because of uncertainties in aerosol-cloud interactions. Here, we use over 10 million satellite observations coupled with aerosol transport model simulations to quantify largescale microphysical effects of aerosols on CF and CP over the Arctic Ocean during polar night, when direct and semi-direct aerosol effects are minimal. Combustion aerosols over sea ice are associated with very large $\left(\sim 10 \mathrm{~W} \mathrm{~m}^{-2}\right)$ differences in longwave cloud radiative effects at the sea ice surface. However, co-varying meteorological changes on factors such as CF likely explain the majority of this signal. For example, combustion aerosols explain at most $40 \%$ of the CF differences between the full dataset and the clean-condition subset, compared to between $57 \%$ and $91 \%$ of the differences that can be predicted by co-varying meteorology. After normalizing for meteorological regime, aerosol microphysical effects have small but significant impacts on $\mathrm{CF}, \mathrm{CP}$, and precipitation frequency on an Arctic-wide scale. These effects indicate that dominant aerosol-cloud microphysical mechanisms are related to the relative fraction of liquid-containing clouds, with implications for a warming Arctic.
\end{abstract}

\section{Introduction}

Cloud cover has a major influence on surface heating, precipitation, and future climate over the Arctic (Boucher et al., 2013) and may play a role in the enhanced warming over the Arctic compared to lower-latitude regions (Södergren et al., 2017), known as Arctic amplification. Aerosols can influence a number of factors relevant to cloud fraction (CF), including cloud droplet number, phase, lifetime, and probability of precipitation (Albrecht, 1989; Coopman et al., 2016; Girard et al., 2005; Lance et al., 2011; Lindsey and Fromm, 2008; Zamora et al., 2017). However, the regional-scale importance of aerosol microphysical processes on $\mathrm{CF}$ has been difficult to constrain from observations and models, particularly due to uncertainties in how aerosols affect precipitation and ice nucleation rates (Gettelman, 2015; Morrison et al., 2012; Ovchinnikov et al., 2014). This is mainly due to the complexity of the responses of different types of clouds to different aerosol types and concentrations (Fan et al., 2016; Fu and Xue, 2017; Stevens et al., 2018; Zhao et al., 2018), poorly constrained aerosol concentrations (particularly in winter and beneath thick cloud cover), and confounding effects from co-varying meteorology (Gryspeerdt et al., 2016). These uncertainties contribute to the large uncertainties in model CF and cloud phase (CP) (de Boer et al., 2011; Cesana and Chepfer, 2012; Chernokulsky and Mokhov, 2012; Kay et al., 2010; Liu et al., 2011; Qian et al., 2012; Stanfield et al., 2014; Zib et al., 2012). To account for the impact of meteorological co-variability on Arctic CF, observations covering large spatial and temporal domains are required, making it difficult to estimate the regional importance of aerosol mi- 
crophysical effects solely from in situ observations. These uncertainties have precluded better constraints on the mechanisms by which aerosols affect cloud microphysics (Morrison et al., 2012) and on general model estimates of their overall importance.

In this paper, we focus on the effects of combustionderived (i.e., anthropogenic pollution plus smoke) aerosols on clouds. Combustion-derived aerosols are strongly impacted by anthropogenic activity and tend to dominate columnar mass under high aerosol optical depth (AOD) conditions in the Arctic (Xie et al., 2018), although in spring the more well-mixed mineral dust can also contribute $10 \%$ to total Arctic AOD levels (Breider et al., 2014; Groot Zwaaftink et al., 2016). Combustion aerosols have pronounced effects on Arctic cloud microphysical and radiative properties (e.g., Carrió et al., 2005; Coopman et al., 2016, 2018; Earle et al., 2011; Garrett et al., 2004; Jouan et al., 2014; Lubin and Vogelmann, 2006; Tietze et al., 2011; Zamora et al., 2016, 2017; Zhao and Garrett, 2015). Their cloud impacts are likely to be particularly large during winter and spring, when they are transported to the Arctic most efficiently, and when precipitation is reduced, causing a peak in aerosol abundance at many remote Arctic ground stations known as Arctic haze (Barrie, 1986; Croft et al., 2016; Quinn et al., 2007; Stohl et al., 2006). However, so far it has been challenging to assess their cloud effects on the Arctic region as a whole, due to large cloud model uncertainties, spatialtemporal observation limitations, and difficulties obtaining some types of remote sensing information at high latitudes.

Here, we provide the first observation-based constraint on combustion aerosol microphysical effects on total nighttime CF over the Arctic Ocean region within the spectrum of current-day aerosol and meteorological conditions. Estimates of combustion aerosol microphysical effects on operational, satellite-defined CF are obtained from 2 years of remote sensing data and output from the FLEXPART (FLEXible PARTicle dispersion model) Lagrangian particle dispersion model (Stohl et al., 1998, 2005). We use the model to provide estimates of how clean or polluted the observed air masses were. We then identify average cloud property differences over sea ice and open ocean regions between the full dataset (hereafter referred to as "all conditions") and a subset where combustion aerosols are at clean background levels ("clean conditions"). By comparing clean to all conditions, as opposed to comparing clean to non-clean or polluted-only conditions, our estimates account for the relatively high frequency of clean and low-aerosol conditions and are more representative of the microphysical effects of combustionderived aerosols over sea ice and open ocean regions. It also reduces the need to introduce an additional, arbitrary pollution threshold. By averaging millions of observations after stratifying them by temperature and relative humidity, we minimize confounding effects of local and large-scale meteorological co-variability. A major strength of this method, which depends primarily on direct observations, is that it re- quires no detailed parameterization of the fraction of cloudactive aerosols or underlying microphysical mechanisms to constrain the importance of large-scale aerosol microphysical effects on Arctic clouds.

\section{Methods}

Tropospheric cloud data gathered from CloudSat and CloudAerosol Lidar and Infrared Pathfinder Satellite Observation (CALIPSO) data during polar night over the Arctic Ocean were collected from 1 January 2008 to 7 December 2009, between 60 and $82^{\circ} \mathrm{N}$ and between 0.6 and $8.5 \mathrm{~km}$ above sea level. These years had typical moisture fluxes and total cloud fractions compared to other recent years (Boisvert and Stroeve, 2015; Kay and L'Ecuyer, 2013). We focused on observations during polar night (solar zenith angle, SZA, $>90^{\circ}$ ) mainly to isolate indirect effects of aerosols on clouds as much as possible from confounding direct and semi-direct aerosol radiative effects. The nighttime focus also reduces uncertainties from any residual diurnal changes in cloud fraction and is associated with a better lidar signal-to-noise ratio (used for aerosol transport model validation, see the Supplemental). Data from all months meeting the above criteria were included, except those between May and July. These were excluded to avoid geographic bias in the analysis, as the few nighttime data that were available during this period tended to occur mainly at the lowest latitudes. Clouds below $0.6 \mathrm{~km}$ were not assessed due to near-ground uncertainties in the CloudSat and CALIPSO data (de Boer et al., 2009; Liu et al., 2017).

Oceanic areas were determined by ETOPO1 bedrock GMT4 data (Amante and Eakins, 2009). Oceanic clouds were separated into open ocean and sea ice regions following Zamora et al. (2017): for each profile, the corresponding monthly fractional sea ice cover was determined from the NOAA/NSIDC Climate Data Record of Passive Microwave Sea Ice Concentration, version 2 (Meier et al., 2013; Peng et al., 2013), and samples associated with $>80 \%$ or $<20 \%$ monthly sea ice fractions were classified as being over sea ice or open ocean, respectively.

\subsection{Aerosol transport model}

Passive remote sensors provide no aerosol data at night and do not provide reliable aerosol data over bright sea ice or under clouds. Active lidar signals are often attenuated in clouds. Moreover, active sensors such as CALIPSO cannot always detect dilute aerosols, even in conditions with the highest lidar sensitivity (i.e., above clouds at night Zamora et al., 2017). Therefore, the presence of combustion aerosols for comparison to the satellite cloud data was estimated with vertically resolved modeled black carbon (BC) aerosol estimates from FLEXPART (Stohl et al., 1998, 2005). Here, FLEXPART was driven with meteorological analysis data from 
the European Centre for Medium-Range Weather Forecasts (ECMWF) at a resolution of $1^{\circ}$ longitude and $1^{\circ}$ latitude. Anthropogenic and biomass burning $\mathrm{BC}$ emissions were based on the ECLIPSE (Evaluating the CLimate and Air Quality ImPacts of Short-livEd Pollutants) (Stohl et al., 2015) and GFED (Global Fire Emission Database) (Giglio et al., 2013) inventories, respectively. Model output was produced in five vertical layers between $0.6-1.5,1.5-2.5,2.5-4,4-6$, and 6$8.5 \mathrm{~km}$. Note that the resolution of the meteorological input data is much higher (91 levels) and, as a Lagrangian model, FLEXPART has no discrete resolution for the particle transport. BC emissions were based on the ECLIPSE emission inventory (Stohl et al., 2015). Note that emission fluxes in the model rely on inventories of emission factor measurements that partially include thermo-optical measurements, which may not always completely differentiate between $\mathrm{BC}$ and "brown" or organic carbon (BrC or OC) (Russell et al., 2014; Samset et al., 2018). Further details on the model and its configuration can be found in Zamora et al. (2017).

FLEXPART is widely used and is well validated for the purpose of studying Arctic smoke and pollution transport (Damoah et al., 2004; Eckhardt et al., 2015; Forster et al., 2001; Paris et al., 2009; Sodemann et al., 2011; Stohl et al., 2002, 2003, 2015; Zamora et al., 2017). FLEXPART BC is used in this study as a proxy for all combustion aerosols, because they very often contain BC, although in somewhat different fractions. The association of high levels of modeled BC with CALIPSO aerosols in general (see Zamora et al., 2017) indicates that modeled BC is a fairly good proxy for strong (CALIPSO-detectable) aerosol layers during polar night, even though some local sources of combustion aerosols (Creamean et al., 2018; Maahn et al., 2017) might not be included in the model. Model comparisons to CALIPSO aerosol data in the study region also indicate that model-identified clean conditions $\left(\mathrm{BC}<30 \mathrm{ng} \mathrm{m}^{-3}\right)$ are associated with significantly lower levels of CALIPSO aerosol layer presence relative to average or polluted conditions (see Supplement for further details).

\subsection{Cloud remote sensing observations}

Cloud fraction is operationally defined based on the CloudSat algorithm, in CloudSat products available at a vertical resolution of $250 \mathrm{~m}$. Cloud base and top heights were originally obtained from the 2B-GEOPROF-LIDAR product (Mace et al., 2009; Mace and Zhang, 2014), and the resulting cloud geometric thickness information was used to obtain a profile of vertical cloud fraction at the FLEXPART model vertical resolution. All vertical cloud fraction profiles (numbering 10422219 total profiles over the Arctic Ocean) that fell within $12.5 \mathrm{~km}^{2}$ stereographic projection grid cells (Cavalieri et al., 2014) were then averaged together. The gridded observations over sea ice (open ocean) include 15999 (31 978) grid cells from fall, 43687 (24008) grid cells from winter, and 38793 (15 289) grid cells from spring, with the observa- tion numbers being a function of sea ice extent and length of darkness periods during each season.

Above $1 \mathrm{~km}$, the 2B-GEOPROF-LIDAR product is similar to or better than ground-based observations, but cloud fraction can be underestimated by up to $\sim 20 \%$ below $\sim 1 \mathrm{~km}$ (Liu et al., 2017), indicating that cloud detection uncertainties in this study's lowest vertical bin $(0.6-1.5 \mathrm{~km})$ are higher there than in other altitude ranges.

CloudSat and CALIPSO do not sample north of $82^{\circ}$. The lack of data within this "pole hole" might mean that those sea ice regions are not well represented in this study. It is unclear how well the data outside the pole hole approximate the data inside it, as this region is the coldest part of the Arctic, and probably also contains some of the cleanest parts with respect to aerosols. Also note that thin-ice-cloud identification is particularly prone to errors over the Arctic, due in part to the widespread occurrence of sub-visible diamond dust and blowing snow. Additionally, the CloudSat radar can sometimes mistake precipitation for clouds (de Boer et al., 2009), which can be particularly problematic under optically thick clouds that completely attenuate the CALIPSO lidar signal, and prevent lidar data from being collected below cloud.

Cloud precipitation presence and phase were obtained from the CloudSat 2B-CLDCLASS-LIDAR version R04 (Wang, 2013). This product captures precipitation with high confidence (Hudak et al., 2008). Phase determination has also been validated favorably at high latitudes (Barker et al., 2008), except that in some cases the radar can misclassify small liquid droplets as ice particles (Noh et al., 2011; Van Tricht et al., 2016). CloudSat may also fail to observe some ice- (IPC) and mixed-phase (MPC) clouds below $1 \mathrm{~km}$ (Liu et al., 2017), suggesting higher uncertainties in cloud phase as well in the lowest vertical bin of this study. Here, cloud phase certainty values were required to be $>5$, indicating a higher confidence in phase classification. If a vertical bin at FLEXPART resolution contained clouds of different phases, that bin was excluded from phase-related portions of the analysis. As with CF data, nearby cloud precipitation and phase profile data were averaged within $12.5 \mathrm{~km}^{2}$ grids at each altitude level prior to analysis.

Estimates of the longwave cloud radiative effect at the bottom of the atmosphere $\left(\mathrm{CRE}_{\mathrm{BOA}}\right)$ were obtained from the CloudSat 2B-FLXHR-LIDAR product, version R04 (Henderson et al., 2012; L'Ecuyer et al., 2008). This product is based on combined CloudSat, CALIPSO, and MODIS observations and time-coincident European Centre for MediumRange Weather Forecasts output of atmospheric humidity, temperature, and sea surface temperature, fed into the BugsRad two-stream, plane-parallel, doubling-adding radiative transfer model, following Henderson et al. (2012). Previous work shows that this product can severely underestimate downwelling LW radiation due to misclassification of small supercooled water as ice particles (Van Tricht et al., 2016) leading to uncertainties in the absolute values of $\mathrm{CRE}_{\mathrm{BOA}}$. Here, we primarily focus on relative differences in $\mathrm{CRE}_{\mathrm{BOA}}$ 
between two subsets of data: those with high and low modeled $\mathrm{BC}$ values. The uncertainty due to misclassification of the small particle phase is similar in both subsets of data, which are collected over the same surfaces and years, allowing for meaningful comparisons to be made between the two datasets despite uncertainty in the absolute values.

\subsection{AIRS observations}

Air mass temperature and relative humidity at pressure levels ranging from 1000 to $250 \mathrm{hPa}$ were obtained from the Atmospheric Infrared Sounder (AIRS) level 3 version 6 dataset (Susskind et al., 2014) on the descending orbit (collected at 01:30 local time). The AIRS instrument provides qualitycontrolled, accurate daily observations over the full study area, including during nighttime conditions, and is validated for use over the Arctic (Boisvert et al., 2015). Data are available in most cloud conditions, although data are not available in completely cloud-covered conditions. Level 3 data, which average observations over a $1 \times 1^{\circ}$ horizontal grid and report at 20 vertical pressure levels, are used instead of level 2 data to obtain the closest approximate $T$ and $\mathrm{RH}$ data when cloud fractions are high. Errors in this product are highest at larger cloud fractions and below optically thick clouds. For comparison to other datasets in this study, AIRS data were averaged into the coarser FLEXPART model vertical resolution.

\subsection{Data analysis}

Differences in relative humidity, temperature, and $12.5 \mathrm{~km}^{2}$ gridded $\mathrm{CF}(\overline{d \mathrm{RH}}, \overline{d T}$, and $\overline{d \mathrm{CF}}$, respectively) between all $\left(\overline{\mathrm{RH}}, \bar{T}\right.$, and $\overline{\mathrm{CF}}$, respectively) and clean $\left(\overline{\mathrm{RH}_{\mathrm{c}}}, \overline{T_{\mathrm{c}}}\right.$, and $\overline{\mathrm{CF}_{\mathrm{c}}}$, respectively) conditions were calculated over sea ice and open ocean regions as follows:

$\overline{d \mathrm{RH}}=\overline{\mathrm{RH}}-\overline{\mathrm{RH}_{\mathrm{c}}}$,

$\overline{d T}=\bar{T}-\overline{T_{\mathrm{c}}}$,

$\overline{d \mathrm{CF}}=\overline{\mathrm{CF}}-\overline{\mathrm{CF}_{\mathrm{c}}}$.

In a process conceptually fairly similar to previous work (Chen et al., 2014) (see Fig. 1 as an example), spatially gridded $\mathrm{CF}$ and $\mathrm{BC}$ data in all and clean $\left(\mathrm{BC}<30 \mathrm{ng} \mathrm{m}^{-3}\right)$ conditions were sorted into $5 \%$ relative humidity bins and $5{ }^{\circ} \mathrm{C}$ temperature bins, and then the differences in all conditions minus clean conditions were compared within each $T-\mathrm{RH}$ bin $\left(d \mathrm{CF}_{T, \mathrm{RH}}\right.$ and $d \mathrm{BC}_{T, \mathrm{RH}}$, respectively). We then compared the differences in all minus clean conditions within each $T-\mathrm{RH}$ bin for the change in cloud fraction $\left(d \mathrm{CF}_{T, \mathrm{RH}}\right)$ black carbon $\left(d \mathrm{BC}_{T, \mathrm{RH}}\right)$, cloud phase $\left(d \mathrm{CP}_{T, \mathrm{RH}}\right)$, and precipitation frequency $\left(d \operatorname{pptn}_{T, \mathrm{RH}}\right)$. Data were analyzed separately over sea ice vs. open ocean and within different altitude layers.

Stratifying by similar $T$ and $\mathrm{RH}$ conditions isolates some of the systematic BC co-variability with $T$ and $\mathrm{RH}$, helping to clarify the $\mathrm{BC}$ aerosol impact on cloud fraction. The $5^{\circ} \mathrm{C}$

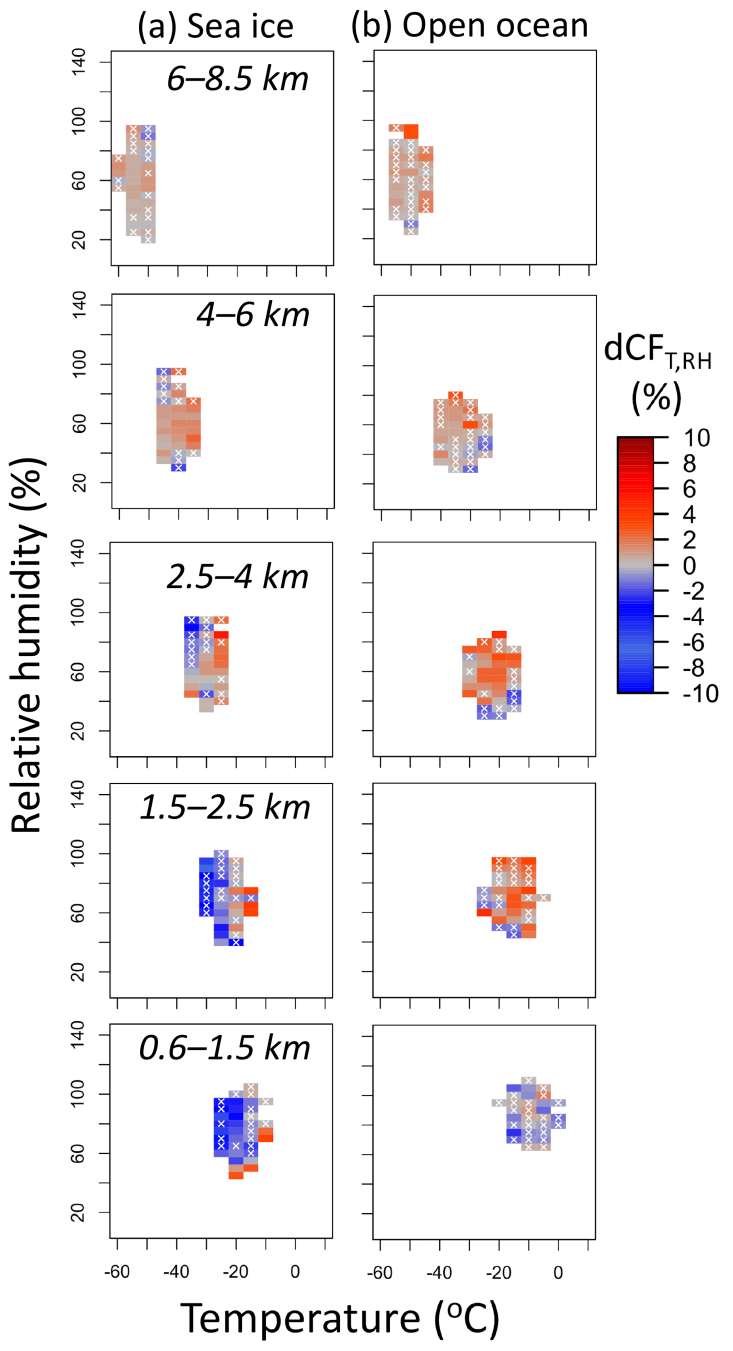

Figure 1. An example of $d \mathrm{CF}_{T, \mathrm{RH}}$ output at each altitude level over (a) sea ice and (b) open ocean. For illustration purposes, here each grid cell represents $\geq 7500 \mathrm{~km}^{2}$ of gridded observations. Blue and red colors indicate negative and positive $d \mathrm{CF}_{T, \mathrm{RH}}$, respectively. A white $\mathrm{X}$ indicates that the cell value is not significantly different from zero (Wilcoxon rank test, $p<0.05$ ). Note that each underlying Wilcoxon rank test has a $5 \%$ chance of yielding a false positive indication of statistical significance or an unknown (but likely much higher) chance of yielding a false negative result. Consequently, the distribution of Xs should not be over-interpreted. The number of Xs, however, provides an objective way to test whether the evidence for an effect on the grid as a whole is significant. This is consistently the case; in all panels, individually significant cells numbered more than expected at random (binomial test, $p<0.001$ ).

$T$ and 5\% RH bin increments were chosen to balance the benefits of larger sample sizes against the drawbacks of reduced bin representativeness at smaller bin sizes. Data plotted at larger bin increments resulted in similar trends (data not shown). 
The estimated microphysical impact of combustion aerosols on total $\mathrm{CF}$ over the Arctic Ocean during polar night is calculated from the mean $d \mathrm{CF}_{T, \mathrm{RH}}$, weighted by the number of $12.5 \mathrm{~km}^{2}$ grids containing observations falling within each RH and $T$ bin, abbreviated as $\overline{d \mathrm{CF}_{T, \mathrm{RH}}}$. Averaging over sea ice and open ocean regions helps reduce the effects of horizontal winds on factors such as aerosol advection, which can co-vary on local scales with aerosols (Engström and Ekman, 2010; Nishant and Sherwood, 2017). That, in combination with accounting for variations in the $T$ and $\mathrm{RH}$ data, enables us to capture several key meteorological parameters that might influence cloud fraction. However, there are no reliable space-borne measurements for vertical velocity, which might also co-vary systematically with $\mathrm{BC}$ on a regional scale, and meteorological reanalyses of large-scale vertical motion over the wintertime Arctic are not well validated (Jakobson et al., 2012). Our focus on nighttime data over the flat ocean surface likely reduces effects from solarheating-driven vertical motion, but the full uncertainty from this parameter cannot be accounted for here. For example, if cold aerosol-containing continental air is routinely advected over warmer open ocean areas, that could induce systemic convection (Serreze and Barry, 2005) that might not be fully captured by the $T$ and RH stratification. To provide at least some generalized grouping of clouds likely to be influenced by different large-scale vertical motion, we analyzed altitude layers and surface types (sea ice and open ocean) separately.

\section{Results}

\subsection{Aerosol microphysical effects on cloud fraction}

Systematic regional co-variability of aerosols and meteorological factors must be accounted for in order to avoid overestimating aerosol impacts on clouds (Coopman et al., 2018; Gryspeerdt et al., 2016). To illustrate this point, Fig. 2 shows the longwave $\mathrm{CRE}_{\mathrm{BOA}}$ for the upper and lower quartiles of FLEXPART model column BC concentrations, calculated during the entire study period. The upper and lower quartile ranges of column BC levels are associated with very large $\left(\sim 10 \mathrm{~W} \mathrm{~m}^{-2}\right)$ differences in median longwave $\mathrm{CRE}_{\mathrm{BOA}}$ over sea ice (Fig. 2). This value is estimated from the median difference in $12.5 \mathrm{~km}^{2}$ gridded $\mathrm{CRE}_{\mathrm{BOA}}$ values over sea ice regions across the Arctic Ocean during the study period, in grid cells with a minimum of at least three observations in the upper and lower quartile ranges of column $\mathrm{BC}$ levels. However, when we compare the median relative humidity and temperature profiles with column BC levels in the upper quartile over sea ice (Fig. 2f, red lines) and open ocean (Fig. 2g, red lines) to the lower quartile profiles (blue lines, same figures), it is clear that column BC levels over sea ice are also associated with noticeable differences in median relative humidity and temperature profiles (Fig. 2f). Small differences in lower tropospheric stability (Fig. 2e), defined as the difference in potential temperature between 700 and $1000 \mathrm{hPa}$, are also observed. These meteorological factors strongly affect $\mathrm{CF}$ and $\mathrm{CP}$, which in turn help drive $\mathrm{CRE}_{\mathrm{BOA}}$. As a result, aerosol microphysical effects may contribute to only a fraction of the $\mathrm{CRE}_{\mathrm{BOA}}$ differences shown in Fig. 2.

To help better understand co-varying meteorological effects on CF specifically, we assessed a generalized additive model (GAM) (Hastie and Tibshirani, 1990) of the $\overline{d \mathrm{RH}}, \overline{d T}$, and $\overline{d \mathrm{CF}}$ data at each vertical level, season, and surface type (Table 1). Seasonal differences in solar illumination, sea ice extent, and BC levels led to some sample number differences for sea ice and open ocean at different times of the year (Table 2). In the GAM, the seasonal values in Table 1 were weighted equally to represent the equal periods of the year being sampled.

The GAM suggests that co-varying differences in $\overline{d \mathrm{RH}}$ and $\overline{d T}$ by themselves can explain up to $91 \%$ of the variability in $\overline{d \mathrm{CF}}$ (as measured by deviance, a statistic similar to variance, Jørgensen, 1997). Because aerosols can covary with $T$ and RH (e.g., because polluted air masses are more likely to have recently resided near the continental surface than clean air masses), aerosols could be responsible for some of this explained variability even without being explicitly included in this GAM. For instance, a GAM based only on $\overline{d \mathrm{BC}}$ explains up to $40 \%$ of $\overline{d \mathrm{CF}}$ variability. A GAM containing $\overline{d \mathrm{BC}}, \overline{d \mathrm{RH}}$, and $\overline{d T}$ explains $97 \%$ of the $\overline{d \mathrm{CF}}$ variability, and thus the lower limit on the temperature and relative humidity influence on mean differences in $\mathrm{CF}$ is $\sim 57 \%$ (97\% minus $40 \%$ ) based on this analysis. The finding that co-varying temperature and relative humidity explain more than half (57\%-91\%) of the $\overline{d \mathrm{CF}}$ variability underscores the importance of interpreting aerosol effects on clouds in the context of co-varying temperature and relative humidity. It also indicates that changes in $T$ and $\mathrm{RH}$ of air masses entering the Arctic could have important impacts on observed $\mathrm{CF}$, to a degree that is likely to be much more regionally important than the microphysical effects of the aerosols themselves.

Cloud fraction substantially differed among all and clean conditions for many combinations of $T, \mathrm{RH}$, altitude, and surface type (Fig. 1). Estimated aerosol impacts on total CF depend on altitude and surface type but are fairly consistent among seasons (Figs. S1-S3 in the Supplement). At the lowest levels $(0.6-2.5 \mathrm{~km}$ over sea ice and $0.6-1.5 \mathrm{~km}$ over open ocean), weighted mean $d \mathrm{CF}_{T, \mathrm{RH}}\left(\overline{d \mathrm{CF}_{T, \mathrm{RH}}}\right)$ is negative, resulting in an $\sim 6 \%$ reduction in $\mathrm{CF}$ relative to clean conditions over sea ice $(-0.6 \%$ over open ocean) (Fig. 3$)$. In contrast, $\overline{d \mathrm{CF}_{T, \mathrm{RH}}}$ between 4 and $8.5 \mathrm{~km}$ elevation increased by $3 \%-5 \%$ over both surfaces, indicating more cloud cover at high altitudes for combustion-aerosol-influenced clouds compared to clean conditions. Absolute $\overline{d \mathrm{CF}_{T, \mathrm{RH}}}$ changes over sea ice and open ocean ranged from $-1.7 \%$ to $0.7 \%$ and $-0.2 \%$ to $1.4 \%$, respectively, depending on altitude. Note that the $\overline{d \mathrm{CF}_{T, \mathrm{RH}}}$ value is based on all $d \mathrm{CF}_{T, \mathrm{RH}}$ data, including those from $T$ and $\mathrm{RH}$ ranges where $d \mathrm{CF}_{T, \mathrm{RH}}$ is 
(a)

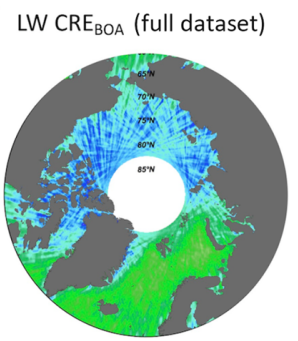

(b) LW CRE $E_{B O A}$ (lower $25 \%$ column BC levels)

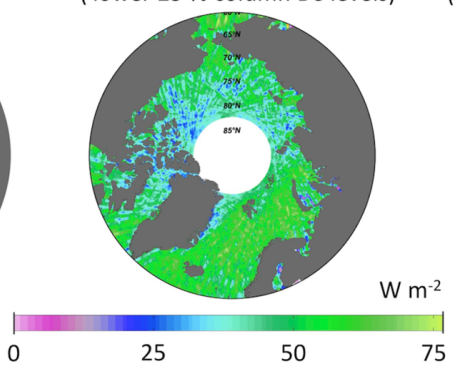

(c) $L W C R E_{B O A}$ (upper $25 \%$ column BC levels)

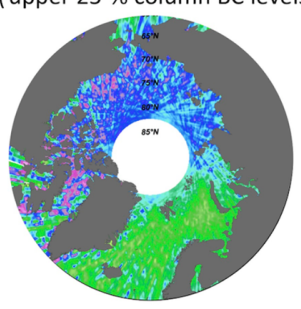

(d)

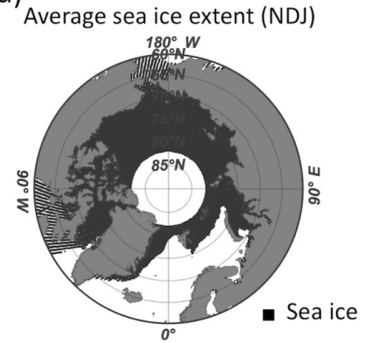

(e)

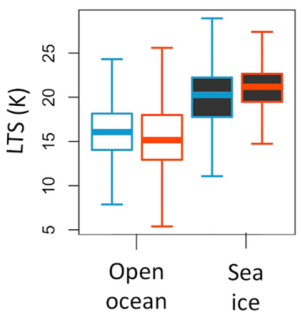

(f)

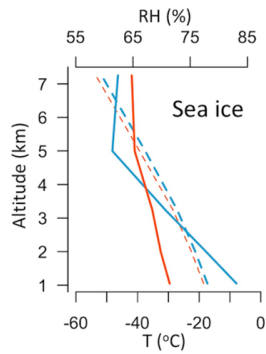

(g)

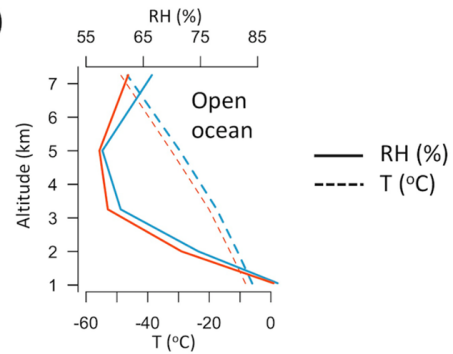

Figure 2. (a-c) CloudSat 2B-FLXHR-LIDAR longwave cloud radiative effect at the bottom of atmosphere (i.e., surface) (LW CRE $\mathrm{BOA}$ ) during polar night for (a) the full dataset, and the subsets of data containing the lower (b) and upper (c) quartiles of modeled column BC concentrations. For reference, (d) shows the average winter (November to January) sea ice extent up to 82 ${ }^{\circ}$ N. Also shown are (e) boxplots of the lower tropospheric stability (LTS, K), and (f) $(\mathbf{g})$ show the median temperature $\left(T,{ }^{\circ} \mathrm{C}\right)$ and relative humidity (RH, \%) for the lower (blue) and upper (red) quartile column BC concentrations over open ocean and sea ice. All differences in (e) $-(\mathbf{g})$ are significant $(p<0.0001)$, based on a Wilcoxon rank test.

Table 1. The mean temperature $\left(T,{ }^{\circ} \mathrm{C}\right)$, relative humidity $(\mathrm{RH}, \%)$, black carbon $\left(\mathrm{BC}, \mathrm{ng} \mathrm{m}^{-3}\right)$, and cloud fraction $(\mathrm{CF}, \%)$ observed over the Arctic Ocean study region over sea ice and open ocean during different seasons and altitude levels. Data are shown for all conditions. Also shown are the mean differences between all minus clean conditions (difference) for $T, \mathrm{RH}, \mathrm{BC}$, and $\mathrm{CF}$, referred to as $\overline{d T}, \overline{d \mathrm{RH}}, \overline{d \mathrm{BC}}$, and $\overline{d \mathrm{CF}}$ in the text.

\begin{tabular}{|c|c|c|c|c|c|c|c|c|c|c|c|c|c|}
\hline & \multirow{3}{*}{$\begin{array}{l}\text { Altitude levels } \\
(\mathrm{km})\end{array}$} & \multicolumn{6}{|c|}{ Sea ice } & \multicolumn{6}{|c|}{ Open ocean } \\
\hline & & \multicolumn{2}{|c|}{ Fall (ASO) } & \multicolumn{2}{|c|}{ Winter (NDJ) } & \multicolumn{2}{|c|}{ Spring (FMA) } & \multicolumn{2}{|c|}{ Fall (ASO) } & \multicolumn{2}{|c|}{ Winter (NDJ) } & \multicolumn{2}{|c|}{ Spring (FMA) } \\
\hline & & all & difference & all & difference & all & difference & all & difference & all & difference & all & difference \\
\hline \multirow{5}{*}{$\begin{array}{l}\text { Temperature } \\
\left({ }^{\circ} \mathrm{C}\right)\end{array}$} & $6-8.5$ & -48.7 & 0.0 & -53.0 & 0.0 & -51.9 & 0.1 & -45.0 & 0.1 & -49.6 & 0.0 & -49.2 & 0.1 \\
\hline & $4-6$ & -32.3 & 0.5 & -38.1 & 0.2 & -40.0 & 0.4 & -27.7 & 0.3 & -33.2 & 0.1 & -35.5 & 0.1 \\
\hline & $2.5-4$ & -21.6 & 0.5 & -27.5 & 0.1 & -29.5 & 0.1 & -15.8 & 0.4 & -21.1 & 0.2 & -23.6 & 0.0 \\
\hline & $1.5-2.5$ & -15.5 & 0.5 & -21.6 & -0.4 & -23.4 & -0.7 & -9.2 & 0.4 & -14.6 & 0.4 & -16.6 & -0.2 \\
\hline & $0.6-1.5$ & -11.3 & 0.4 & -17.7 & -0.6 & -19.6 & -1.3 & -4.5 & 0.3 & -9.9 & 0.4 & -11.6 & -0.3 \\
\hline \multirow{5}{*}{$\begin{array}{l}\text { Relative } \\
\text { humidity } \\
(\%)\end{array}$} & $6-8.5$ & 74.6 & 0.0 & 65.6 & 0.4 & 50.4 & 1.0 & 69.0 & 0.1 & 63.8 & 0.2 & 50.9 & 0.4 \\
\hline & $4-6$ & 61.5 & -0.3 & 62.7 & 0.4 & 59.8 & -0.6 & 57.1 & -0.1 & 57.6 & 0.6 & 58.5 & 0.9 \\
\hline & $2.5-4$ & 66.7 & -0.6 & 69.3 & 0.2 & 66.2 & -1.8 & 61.4 & 0.2 & 58.6 & 1.6 & 57.1 & 0.6 \\
\hline & $1.5-2.5$ & 76.9 & -0.9 & 74.0 & -0.4 & 68.2 & -0.3 & 74.5 & 0.2 & 72.5 & 1.9 & 69.1 & 0.5 \\
\hline & $0.6-1.5$ & 85.1 & -0.3 & 78.1 & -2.2 & 70.6 & 0.2 & 87.2 & -0.3 & 88.6 & 1.7 & 84.4 & -0.2 \\
\hline \multirow{5}{*}{$\begin{array}{l}\mathrm{BC} \\
\left(\mathrm{ng} \mathrm{m}^{-3}\right)\end{array}$} & $6-8.5$ & 14 & 1 & 13 & 2 & 19 & 5 & 14 & 2 & 11 & 1 & 17 & 3 \\
\hline & $4-6$ & 17 & 3 & 22 & 6 & 30 & 11 & 17 & 3 & 18 & 3 & 28 & 9 \\
\hline & $2.5-4$ & 20 & 4 & 31 & 13 & 41 & 19 & 19 & 5 & 28 & 10 & 38 & 16 \\
\hline & $1.5-2.5$ & 20 & 4 & 39 & 21 & 53 & 27 & 22 & 7 & 43 & 23 & 47 & 22 \\
\hline & $0.6-1.5$ & 17 & 3 & 51 & 31 & 66 & 32 & 22 & 9 & 58 & 34 & 56 & 27 \\
\hline \multirow{5}{*}{$\begin{array}{l}\text { Mean CF } \\
(\%)\end{array}$} & $6-8.5$ & 15.4 & 0.2 & 15.0 & 0.4 & 9.1 & 0.9 & 19.3 & 1.0 & 22.3 & 0.4 & 15.3 & 0.5 \\
\hline & $4-6$ & 22.7 & 0.6 & 21.8 & 1.3 & 16.8 & 0.1 & 24.3 & 0.8 & 26.0 & 0.8 & 22.7 & 0.7 \\
\hline & $2.5-4$ & 29.1 & 1.0 & 25.9 & 1.0 & 20.8 & -2.1 & 27.9 & 1.0 & 28.8 & 2.2 & 27.4 & 0.5 \\
\hline & $1.5-2.5$ & 35.0 & -0.3 & 30.3 & -0.4 & 24.0 & -3.5 & 34.3 & 1.4 & 39.4 & 2.1 & 39.5 & 0.3 \\
\hline & $0.6-1.5$ & 33.3 & -0.2 & 26.9 & -2.0 & 22.0 & -3.0 & 35.0 & -0.3 & 43.0 & -0.4 & 43.6 & -0.3 \\
\hline
\end{tabular}


Table 2. Total profile numbers during each season of the study over sea ice and open ocean regions. Also shown are the percent of samples determined to be clean $\left(\mathrm{BC}<30 \mathrm{ng} \mathrm{m}^{-3}\right)$ at different altitudes. Seasonal differences in sample numbers depend on factors such as solar illumination; sea ice extent; and, for clean samples, seasonal variations in BC levels.

\begin{tabular}{|c|c|c|c|c|c|c|c|}
\hline & & \multicolumn{3}{|c|}{ Sea ice } & \multicolumn{3}{|c|}{ Open ocean } \\
\hline & & Fall (ASO) & Winter (NDJ) & Spring (FMA) & Fall (ASO) & Winter (NDJ) & Spring (FMA) \\
\hline Total samples & & 457504 & 4687541 & 1757034 & 1153806 & 1429840 & 529904 \\
\hline \multirow[t]{6}{*}{$\begin{array}{l}\% \text { clean } \\
\text { samples }\end{array}$} & $\begin{array}{l}\text { Altitude levels } \\
(\mathrm{km})\end{array}$ & & & & & & \\
\hline & $6-8.5$ & $94 \%$ & $94 \%$ & $85 \%$ & $92 \%$ & $97 \%$ & $89 \%$ \\
\hline & $4-6$ & $88 \%$ & $81 \%$ & $68 \%$ & $88 \%$ & $88 \%$ & $69 \%$ \\
\hline & $2.5-4$ & $85 \%$ & $65 \%$ & $54 \%$ & $83 \%$ & $70 \%$ & $59 \%$ \\
\hline & $1.5-2.5$ & $83 \%$ & $51 \%$ & $39 \%$ & $81 \%$ & $54 \%$ & $50 \%$ \\
\hline & $0.6-1.5$ & $88 \%$ & $46 \%$ & $27 \%$ & $83 \%$ & $50 \%$ & $48 \%$ \\
\hline
\end{tabular}

not significantly different from zero (i.e., as indicated by the white Xs in Fig. 1). Including all data avoids biasing the results in favor of the meteorological conditions where $d \mathrm{CF}_{T, \mathrm{RH}}$ is most observable.

The $d \mathrm{CF}_{T, \mathrm{RH}}$ and $d \mathrm{BC}_{T, \mathrm{RH}}$ relationships (Fig. 4) indicate that there was more cloud cover in slightly polluted conditions but less cloud cover at higher $d \mathrm{BC}_{T, \mathrm{RH}}$ levels ( $>10$ $20 \mathrm{ng} \mathrm{m}^{-3}$ ) relative to clean conditions. $d \mathrm{CF}_{T, \mathrm{RH}}$ declined significantly at $d \mathrm{BC}_{T, \mathrm{RH}}>20 \mathrm{ng} \mathrm{m}^{-3}$ within most individual altitude layers over sea ice and over open ocean at $1.5-2.5 \mathrm{~km}$ (Fig. 3).

Note that the fall period typically has cleaner and warmer conditions compared to winter and spring (Table 1), which tend to occur more heavily on opposite sides of the scatter plots for each altitude layer in Fig. 4. Thus, any large, systematic differences in the vertical winds between fall and spring could influence the outermost points within individual altitude layers, and it is not easy to control for this effect. However, the trends among altitude layers show that $d \mathrm{CF}_{T, \mathrm{RH}}$ is essentially identical over sea ice and open ocean at low $d \mathrm{BC}_{T, \mathrm{RH}}$ values, which occur mostly at high altitudes. Also, $d \mathrm{CF}_{T, \mathrm{RH}}$ changes at high $d \mathrm{BC}_{T, \mathrm{RH}}$ and low altitude are more observable over sea ice (Fig. 4), where lower tropospheric stability was greater and temperatures were colder (Fig. 2e-g). Previous studies have also observed more apparent aerosol microphysical effects under more stable conditions in the Arctic (Coopman et al., 2018; Zamora et al., 2017). Possible reasons for the disparate behavior at different altitudes are discussed below.

\subsection{Aerosol microphysical effects on cloud-phase partitioning}

Weighted mean differences in $\mathrm{CP}$ partitioning between all minus clean conditions within the same $T$ and $\mathrm{RH}$ bins $\left(\overline{d \mathrm{CP}_{T, \mathrm{RH}}}\right)$ are discussed for clouds between 0.6 and $4 \mathrm{~km}$, because clouds at higher altitudes occur mostly in the ice phase (Fig. 5a) (Devasthale et al., 2011a; Liu et al., 2017).
Over sea ice between 0.6 and $4 \mathrm{~km}$, all air masses contained a higher relative fraction of ice-phase clouds (IPCs) and a lower relative fraction of liquid-phase clouds (LPCs) and mixed-phase clouds (MPCs) relative to clean air masses (Fig. 3). This effect was significant up to $4 \mathrm{~km}$ (paired Wilcoxon rank test, $p<0.05$, Sokal and Rohlf, 1995), except in LPCs between 2.5 and $4 \mathrm{~km}$, where lower sample numbers might obscure any changes. Changes in phase partitioning over the sea ice region varied between $-4.2 \%$ and $6.5 \%$, depending on altitude and phase (Fig. 3). From Fig. 3, over sea ice between 1.5 and $2.5 \mathrm{~km}$, the relative contributions of LPCs and MPCs were significantly lower at high $d \mathrm{BC}_{T, \mathrm{RH}}$ levels $\left(>20 \mathrm{ng} \mathrm{m}^{-3}\right)$, whereas that of IPCs was significantly higher. No significant relationships with $d \mathrm{BC}_{T, \mathrm{RH}}$ were observed above or below that altitude, although higher $\mathrm{BC}$ and $\mathrm{CP}$ uncertainties near the surface might mask weak signals in that altitude range. The reduction in liquid-containing clouds at higher $d \mathrm{BC}_{T, \mathrm{RH}}$ levels over sea ice is consistent with a glaciation effect (Lohmann, 2002), whereby increased presence of aerosols leads to ice particle formation and cloud dissipation, as observed in Sect. 3.1.

Over open ocean, significant changes in $\overline{d \mathrm{CP}_{T, \mathrm{RH}}}$ were observed less frequently (Fig. 3), and they tended to be smaller than over sea ice (absolute values $<2 \%$ ). The relative fraction of liquid clouds was reduced between 0.6 and $1.5 \mathrm{~km}$ (Fig. 3), where LPC fractions were highest (Fig. 5a). However, unlike over sea ice, the relative fraction of MPCs over open ocean increased (though not significantly so between 1.5 and $2.5 \mathrm{~km}$ ) and that of IPCs decreased (significant only between 2.5 and $4 \mathrm{~km}$ ). The reason for the different effects on ice-containing clouds over sea ice and open ocean is unclear, although the higher temperatures may play a role.

\subsection{Aerosol microphysical influences on precipitation frequency}

Differences in precipitation frequency, $d \operatorname{pptn}_{T, \mathrm{RH}}$, reflect aerosol microphysical impacts on (1) the frequency of pre- 

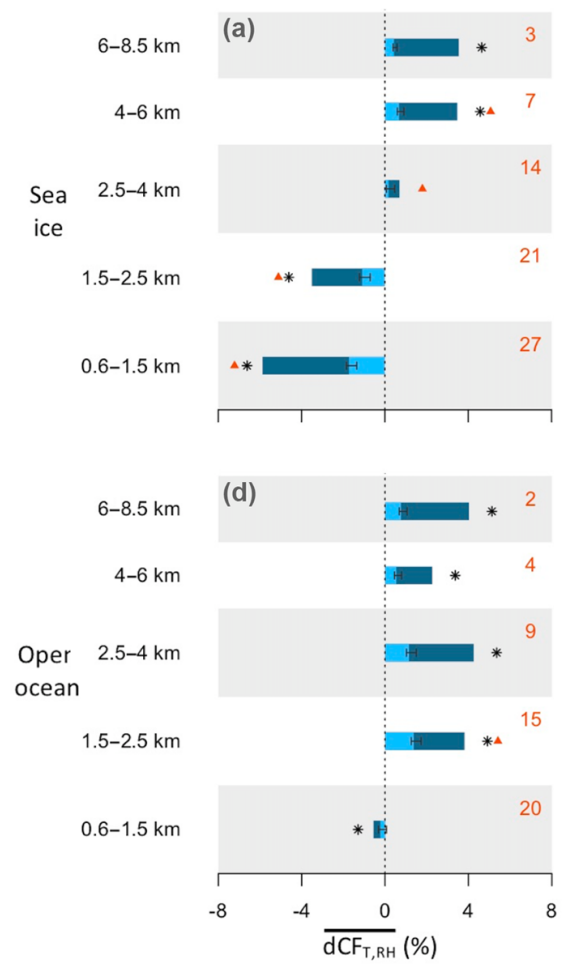
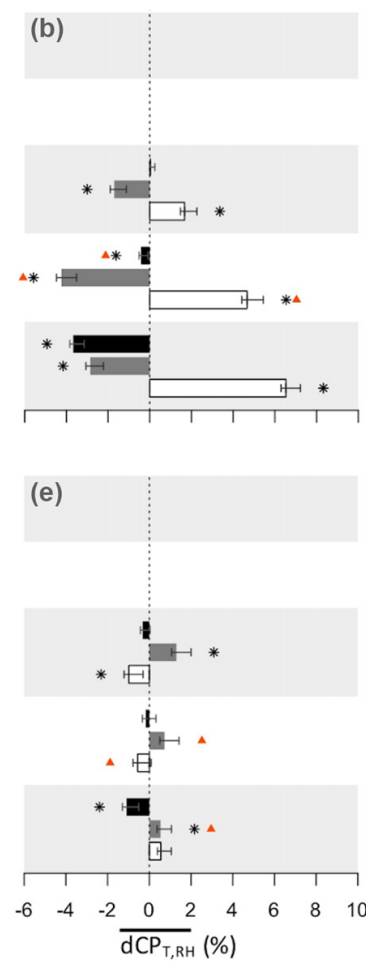
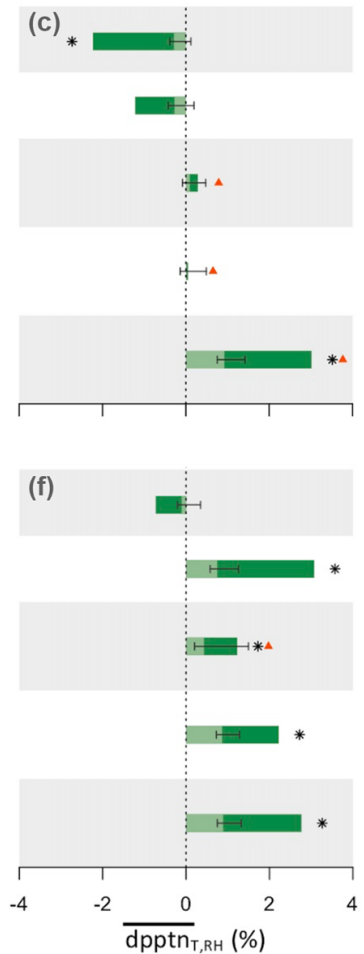

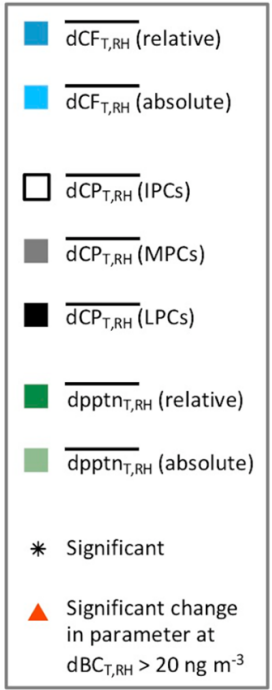

Figure 3. Summary of $\overline{d \mathrm{CF}_{T, \mathrm{RH}}}, \overline{d \mathrm{CP}_{T, \mathrm{RH}}}$ (up to $4 \mathrm{~km}, \%$ ), and $\overline{d \operatorname{pptn}_{T, \mathrm{RH}}}(\%)$ in different altitude ranges over sea ice and open ocean. For $\overline{d \mathrm{CF}_{T, \mathrm{RH}}}$ and $\overline{d \mathrm{pptn}_{T, \mathrm{RH}}}$, different color bars (overlaid, not stacked) show the absolute change within the air volume of interest (lighter colors) and the relative percent change with respect to the value found in clean conditions (darker colors). The $\overline{d \mathrm{BC}_{T, \mathrm{RH}}}$ values (ng $\mathrm{m}^{-3}$ ) are presented for each altitude (red, upper right in $\mathbf{a}$ and $\mathbf{d}$ ). An asterisk (*) indicates that the differences between all and clean conditions were significant for both relative and absolute values, based on a paired Wilcoxon rank test, $p<0.05$, using $T-\mathrm{RH}$ grid cells containing $>800$ (400 for $\overline{d \mathrm{CP}_{T, \mathrm{RH}}}$ ) $12.5 \mathrm{~km}^{2}$ gridded observations. Values marked by a red triangle indicate a significant change in the parameter where $d \mathrm{BC}_{T, \mathrm{RH}}>20 \mathrm{ng} \mathrm{m}^{-3}$ (Wilcoxon rank test, $p<0.05$ ). Error bars show bootstrapped $95 \%$ confidence intervals for the weighted mean. (a) Sea ice

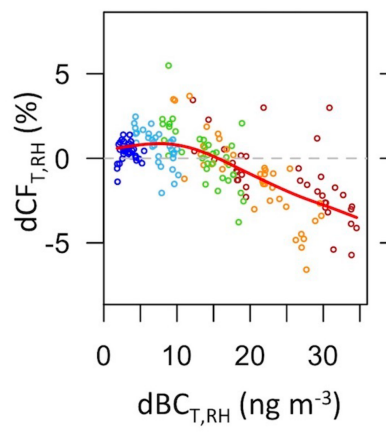

(b) Open ocean

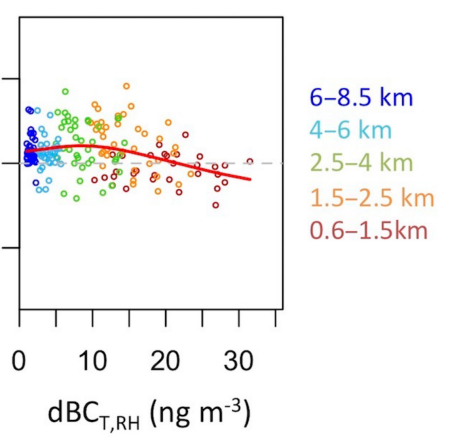

Figure 4. The relationship between $d \mathrm{CF}_{T, \mathrm{RH}}(\%)$ and $d \mathrm{BC}_{T, \mathrm{RH}}$ $\left(\mathrm{ng} \mathrm{m}^{-3}\right)$ over (a) sea ice and (b) open ocean at different altitude levels (color coded) for the points plotted in Fig. 1. The red line is a cubic smoothing spline of the data among all altitudes. In order to avoid obscuring emergent properties of the full dataset, the data include all meteorological conditions, including those where $d \mathrm{CF}_{T, \mathrm{RH}}$ values are not significantly different from zero (as noted by white Xs in Fig. 1). cipitation within a specific air volume and (2) the relative likelihood of individual cloud phases within that air volume to be precipitating. We analyze the difference in precipitation frequency; however, an analysis of total precipitation amounts or precipitating particle microphysics is beyond the scope of this study.

Based on weighted mean $d \operatorname{pptn}_{T, \mathrm{RH}}$ values $\left(\overline{d \mathrm{pptn}_{T, \mathrm{RH}}}\right)$, estimated aerosol microphysical effects on regional preciptudes (Figs. 3, S4). In all air mass conditions, precipitation frequency was $1.2 \%-3.1 \%$ higher below $6 \mathrm{~km}$ over open ocean and below $1.5 \mathrm{~km}$ over sea ice relative to clean conditions, depending on altitude (Fig. 3). In contrast, clean clouds between 6 and $8.5 \mathrm{~km}$ over open ocean were slightly more likely to be precipitating $\left(\overline{d \operatorname{pptn}_{T, \mathrm{RH}}} \sim-1 \%\right)$.

Over sea ice, $\sim 94 \%$ of MPCs were present below $4 \mathrm{~km}$ (Fig. 5a). In these MPCs, $\overline{d \operatorname{pptn}_{T, \mathrm{RH}}}$ was positive $(\sim+1 \%)$, indicating slightly more frequent precipitation on average in all vs. clean MPCs (Fig. 5b). Significant differences between all and clean conditions were not observed for $\overline{d \operatorname{pptn}_{T, \mathrm{RH}}}$ in IPCs or LPCs over sea ice, except for a slight $(-0.4 \%)$ itation frequency were small but significant at many alti- 
(a)
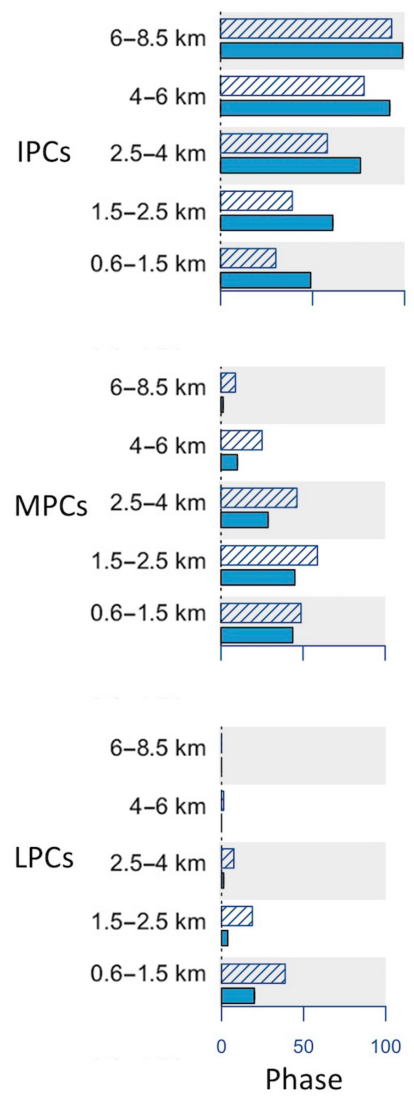

contribution (\%)

Solid = sea ice; hatched $=$ open ocean

Figure 5. The absolute changes in (a) $\mathrm{CP}$ distribution (blue) and (b) $\overline{d \operatorname{pptn}_{T, \mathrm{RH}}}$ (green) for IPCs, MPCs, and LPCs over sea ice (solid) and open ocean (hatched) at different altitude ranges. An asterisk (*) indicates that the differences between all and clean conditions were significant for both relative and absolute values, based on a paired Wilcoxon rank test, $p<0.05$, using $T-\mathrm{RH}$ grid cells containing $>800$ (400 for $\overline{d \mathrm{CP}_{T, \mathrm{RH}}}$ ) $12.5 \mathrm{~km}^{2}$ gridded observations. Error bars show bootstrapped $95 \%$ confidence intervals for the weighted mean.

reduction in $\overline{d \operatorname{pptn}_{T, \mathrm{RH}}}$ in ice clouds at $6-8.5 \mathrm{~km}$ (Fig. $5 \mathrm{~b}$ ). However, significant rank correlations (Kendall's tau coefficient $=0.3, p<0.05$ ) indicate that higher $d \mathrm{BC}_{T, \mathrm{RH}}$ values were associated with slightly more frequent IPC precipitation over sea ice between 0.6 and $1.5 \mathrm{~km}$ (also see Fig. S5). We observed no strong link between $d \mathrm{BC}_{T, \mathrm{RH}}$ and $d \operatorname{pptn}_{T, \mathrm{RH}}$ at other locations/altitudes.

As over sea ice, MPC $\overline{d \operatorname{pptn}_{T, \mathrm{RH}}}$ was slightly positive $(\leq 1 \%)$ below $4 \mathrm{~km}$ over open ocean (Fig. $5 \mathrm{~b}$ ), indicating slightly more MPC precipitation in all vs. clean conditions. IPC $\overline{d \operatorname{pptn}_{T, \mathrm{RH}}}$ was also slightly positive between 1.5 and $4 \mathrm{~km}$, whereas liquid cloud $\overline{d \operatorname{pptn}_{T, \mathrm{RH}}}$ was slightly negative between 1.5 and $4 \mathrm{~km}$. Between 6 and $8.5 \mathrm{~km}$ over open ocean, the $\overline{d \operatorname{pptn}_{T, \mathrm{RH}}}$ in MPCs was slightly negative at $\sim$ $-1 \%$ (Fig. 5b).

Based on single or small cloud samples, others have observed decreased precipitation probability with increased aerosol concentrations in Arctic MPCs (Lance et al., 2011; Morrison et al., 2008). It is not entirely clear why the largescale, regional trends observed here appear to be opposite these smaller-scale in situ observations, but recent work indicates that aerosols might influence ice content of the clouds and thereby affect precipitation (Fu and Xue, 2017; Norgren et al., 2018; Zamora et al., 2017) and potentially CF. Perhaps lower total $\mathrm{CF}$ below $4 \mathrm{~km}$ leads to less frequent precipitation in these air volumes over the Arctic. The higher MPC precipitation probability and lower MPC cover (as indicated by reduced MPC relative fraction of total CF) at higher aerosol concentrations support this hypothesis.

\section{Discussion - potential aerosol microphysical mechanisms}

Specific aerosol-cloud microphysical mechanisms are difficult to identify with confidence from space-borne measurements alone, but some possibilities can be explored. At high altitudes $(6-8.5 \mathrm{~km})$ over sea ice, $\overline{d \mathrm{CF}_{T, \mathrm{RH}}}$ was higher and $\overline{d \operatorname{pptn}_{T, \mathrm{RH}}}$ was lower in all vs. clean conditions (Fig. 3), supporting the hypothesis that aerosols are modifying cloud properties on a regional (i.e., sea ice and open ocean) scale at these altitudes, even though the net changes were relatively small. These modifications to predominantly IPCs at high altitude likely involve aerosol effects on ice crystal formation or properties. Oreopoulos et al. (2017) similarly reported global-scale increases in ice $\mathrm{CF}$ with higher aerosol concentration in their CR1 cases (typically high ice clouds of small optical thickness over the tropics), which was linked to reduced ice cloud effective radius.

There are several mechanisms by which aerosols might modify ice crystal number or size that could cause the observed changes in precipitation and CF in the $6-8.5 \mathrm{~km}$ range. Although $\mathrm{BC}$ itself is not a good source of ice nucleating particles (INPs; Vergara-Temprado et al., 2018), combustion aerosols associated with BC might act as INPs (Kanji et al., 2017) at the extreme cold temperatures found at highaltitude Arctic polar night. This could potentially lead to smaller, more numerous ice particles that precipitate less (Lohmann and Feichter, 2005), in line with our observations, although some models suggest that INPs may instead lead to larger ice crystals in cirrus clouds compared to homogeneous freezing (Heymsfield et al., 2016). Alternatively, combustion aerosols might reduce the efficiency of preexisting INPs through the deactivation effect (Archuleta et al., 2005; Cziczo et al., 2009). Reduced ice crystal formation rates could then lead to more frequent air mass saturation with respect to liquid water; more water droplets that freeze homogeneously; and smaller, more numerous ice particles, and 
less precipitation (Girard et al., 2013) as observed here. This effect could lead to enhanced total CF over the Arctic (Du et al., 2011). Although absolute humidity within the different $T$-RH bins between 6 and $8.5 \mathrm{~km}$ is not systematically related to higher $d \mathrm{BC}_{T, \mathrm{RH}}$ levels as one might expect with the deactivation effect, it is possible that presorting the data by $5 \% \mathrm{RH}$ bins to reduce the impacts of meteorological covariation could make evidence for this effect more difficult to observe. Therefore, it is difficult to say whether this study is consistent with the deactivation effect hypothesis, but it does not preclude it.

The specific microphysical mechanisms affecting loweraltitude clouds are more challenging to identify without in situ data due to the high prevalence of liquid-containing clouds (Fig. 5a). Combustion aerosols can affect precipitation rates by changing droplet numbers and sizes, and thereby possibly collision and coalescence (Albrecht, 1989), riming (Lohmann and Feichter, 2005; Saleeby et al., 2009), or freezing (Bigg, 1953). If these aerosols affect INP levels, they could also affect ice nucleation rates and ice particle concentrations, leading to MPC and LPC glaciation, enhanced precipitation, and reduced cloud cover (the glaciation effect). Our observations do support the possibility of a glaciation effect, because once $T$ and RH co-variability are accounted for all air masses at low altitudes ( 0.6 to $1.5-2.5 \mathrm{~km}$ ) have lower $\mathrm{CF}$ compared to clean conditions. They also have more frequent precipitation in IPCs at high $d \mathrm{BC}_{T, \mathrm{RH}}$, and a higher relative fraction of IPCs over sea ice and MPCs over the warmer open ocean. Each of these changes is significantly different between low and high $d \mathrm{BC}_{T, \mathrm{RH}}$ concentrations at a variety of altitudes and surface types (Fig. 3), suggesting that aerosols may help convert liquid droplets to larger ice particles that precipitate out and reduce $\mathrm{CF}$ in lower-altitude clouds.

These observations are in line with other studies indicating that aerosols can dissipate Arctic MPCs (Fu and Xue, 2017; Norgren et al., 2018) and increase their precipitation (Kravitz et al., 2014; Morrison et al., 2011). Assuming they act as INPs, various modeling studies and a remote sensing study also suggest that aerosols can reduce liquid water path or supercooled water frequency (Fan et al., 2009; Morrison et al., 2011; Ovchinnikov et al., 2014; Pinto, 1998; Tan et al., 2014). The observations over sea ice contrast with some model predictions that MPCs should increase in more polluted conditions through the deactivation effect (Du et al., 2011; Girard et al., 2005, 2013). They also contrast with a previous remote sensing study (Zamora et al., 2017) indicating that thin and predominantly liquid Arctic Ocean clouds are more likely to be the liquid phase at high BC concentrations. However, the clouds in that study may not be fully comparable, as they constitute only $\sim 5 \%$ of the cloud types in this study. Note that shortwave processes might alter how aerosols impact mixed-phase CF during daytime (Solomon et al., 2015), and any such effects would not be observed in the current nighttime study. Changes in higher-altitude clouds might also change underlying cloud properties through a seeding effect, which could impact cloud properties at lower altitudes.

\section{Summary and conclusions}

Upper quartile levels of total column BC (a proxy for combustion aerosols) are associated with very large $\left(\sim 10 \mathrm{~W} \mathrm{~m}^{-2}\right)$ differences in longwave cloud radiative effects at the sea ice surface compared to the lower quartile column BC levels. However, relative humidity in particular over sea ice is very different in the two aerosol conditions, which likely drives much of the $\mathrm{CRE}_{\mathrm{BOA}}$ differences in Fig. 2. The $\mathrm{CRE}_{\mathrm{BOA}}$ is impacted to a high degree by $\mathrm{CF}$. We found that $\mathrm{BC}$ predicted at most $40 \%$ of the observed differences in sea ice and open ocean CF between all and clean conditions in the altitude ranges of interest in this study (0.6$8.5 \mathrm{~km}$ ), whereas AIRS-derived temperature and relative humidity predicted between $57 \%$ and $91 \%$ of the differences. These observations indicate that changes in $T$ and RH of air masses entering the Arctic will likely have a more regionally important influence on observed $\mathrm{CF}$ than the microphysical effects of the aerosols themselves, although aerosols cannot be ignored. In line with previous studies (e.g., Gryspeerdt et al., 2016; Coopman et al., 2018), these results also underscore the need for large sample volumes to identify systematic air mass differences between clean and all conditions, as well as a way to reduce the confounding effects of meteorological co-variation on these samples. To accomplish this, we analyzed over 10 million profiles across the Arctic Ocean, which were binned into similar $T$ and RH groups. We analyzed the data separately over sea ice vs. open ocean and within different altitude layers.

In general, combustion aerosol microphysical effects were most observable where the highest aerosol effect would be expected: (a) at lower altitudes, where aerosol concentrations are often higher (Devasthale et al., 2011b); and (b) over sea ice, where atmospheric stability is greater and aerosol microphysical effects on clouds are less likely to be overwhelmed by meteorological factors such as high vertical velocity. Relative to clean conditions, low clouds over sea ice had $\sim 6 \%$ smaller CF and $3 \%$ higher precipitation frequency, whereas at high altitudes $\mathrm{CF}$ increased by $4 \%$ and precipitation was $2 \%$ less frequent. Similar but smaller trends in CF and lowaltitude precipitation were observed over open ocean. Below $1.5 \mathrm{~km}$, we also observed a $7 \%$ reduction in the LPC and MPC fractions over sea ice, but a slight increase in MPCs relative to LPCs over open ocean. The different effect on MPCs over sea ice and open ocean may be related to the higher temperatures over open ocean, leading to less efficient ice formation or to some other, as yet unknown, factor. Observations from others (e.g., Chernokulsky et al., 2017; Eastman and Warren, 2010) show that expansion of open ocean areas appears to be connected to changing Arctic Ocean cloud 
properties. The different cloud responses to aerosols that we observe over sea ice vs. open ocean may provide partial clues into the cause of this behavior and into the future impacts of combustion aerosols on the Arctic system in general.

These results are subject to various uncertainties, including possible confounding influences from large-scale vertical motion that is difficult to measure in situ, any systematic model errors in identifying aerosol layers at the right altitude (see Supplement), and the uncertain relationships between modeled BC and INP and cloud condensation nuclei $(\mathrm{CCN})$ concentrations. Associations between $d \mathrm{BC}_{T, \mathrm{RH}}$ and cloud properties may be difficult to observe given the low $\mathrm{BC}$ concentrations at altitudes $>4 \mathrm{~km}$ and may be further masked by complex aerosol-cloud relationships. Despite these uncertainties, significant differences in $d \mathrm{CF}_{T, \mathrm{RH}}, d \mathrm{pptn}_{T, \mathrm{RH}}$, and $d \mathrm{CP}_{T, \mathrm{RH}}$ at high $d \mathrm{BC}_{T, \mathrm{RH}}$ concentrations provide evidence that aerosol microphysical effects were driving the observed patterns, as opposed to some other factor. Furthermore, these observations leave open the possibility that other cloud property relationships with $d \mathrm{BC}_{T, \mathrm{RH}}$ exist, but are not observable with the available data.

The mechanisms responsible for these changes cannot be fully elucidated from modeling and remote sensing data alone. The observed increases in $\mathrm{CF}$ and decreases in precipitation at 6-8.5 km likely involve aerosol effects on ice crystal formation or properties, given that nearly all of these clouds are in the ice phase. These effects might include a deactivation of preexisting INPs, or conversely an enhancement of INPs by combustion aerosols themselves at the very low temperatures observed at these high altitudes during Arctic polar night. The reduced $\mathrm{CF}$, more frequent precipitation in mixed-phase clouds, and reduced relative fraction of mixed (liquid) phase clouds over sea ice (open ocean) seem to point towards aerosols either participating in the conversion of liquid droplets to larger ice particles that precipitate and reduce $\mathrm{CF}$, similar to a glaciation effect, or potentially to their impacts on precipitation in higher clouds, changing underlying cloud properties through a seeding effect. Further focused studies on these mechanisms would be of great interest, along with targeted aircraft measurements of the relevant aerosol and cloud properties, providing greater detail at higher spatial and temporal resolution. To improve quantification of Arctic aerosol-cloud microphysical interactions from space, two major uncertainties also require better quantification: (1) large-scale vertical motion and (2) altitude-resolved aerosol amount and type information. Obtaining more ground-based observations of clouds lower than $0.6 \mathrm{~km}$, which are radiatively significant but not measured well by satellite, is also important.

Data availability. CloudSat data were obtained from the CloudSat Data Processing Center of the Cooperative Institute of Research in the Atmosphere (http://www.cloudsat.cira.colostate.edu, last access: 22 June 2017). AIRS data were obtained from AIRS Science
Team/Joao Texeira (2013). For access to the CALIPSO, ETOPO, and NSIDC data, see CALIPSO Science Team (2016), Amante and Eakins (2009), and Meier et al. (2013), respectively. The data underlying Figs. 1, 2, and 4 are presented in text files in the Supplement, and the data from Figs. 3 and 5 are presented tabularly in Table S1.

Supplement. The supplement related to this article is available online at: https://doi.org/10.5194/acp-18-14949-2018-supplement.

Author contributions. LMZ, RAK, and KBH designed the study and the statistical analysis. LMZ processed the satellite data, and AS and SE processed FLEXPART model output. LMZ wrote the manuscript. All authors contributed to revising the manuscript.

Competing interests. The authors declare that they have no conflict of interest.

Acknowledgements. The authors would like to thank Andrew Ackerman, Gijs De Boer, Jessie Creamean, Ann Fridlind, Brad Hegyi, Kyu-Myong Kim, Tristan L'Ecuyer, Jim Limbacher, Greg McFarquhar, Lazaros Oreopoulos, and Joel Susskind for helpful discussions, as well as two anonymous reviewers. CALIPSO data were provided by the NASA Langley Research Center Atmospheric Science Data Center, and the CIRA CloudSat Data Processing Center provided the CloudSat data. The work of Lauren M. Zamora and Ralph A. Kahn is supported in part by NASA's Climate and Radiation Research and Analysis Program under Hal Maring and NASA's Atmospheric Composition Program under Richard Eckman and Ken Jucks.

Edited by: Graham Feingold

Reviewed by: two anonymous referees

\section{References}

AIRS Science Team/Joao Texeira: AIRS/Aqua L3 Daily Standard Physical Retrieval (AIRS+AMSU) 1 degree x 1 degree V006, Greenbelt, MD, USA, Goddard Earth Sciences Data and Information Services Center (GES DISC), https://doi.org/10.5067/Aqua/AIRS/DATA301, 2013.

Albrecht, B. A.: Aerosols, Cloud Microphysics, and Fractional Cloudiness, Science, 245, 1227-1230, https://doi.org/10.1126/science.245.4923.1227, 1989.

Amante, C. and Eakins, B. W.: ETOPO1 1 Arc-Minute Global Relief Model: Procedures, Data Sources and Analysis. NOAA Technical Memorandum NESDIS NGDC-24. National Geophysical Data Center, NOAA, https://doi.org/10.7289/V5C8276M, 2009.

Archuleta, C. M., DeMott, P. J., and Kreidenweis, S. M.: Ice nucleation by surrogates for atmospheric mineral dust and mineral dust/sulfate particles at cirrus temperatures, Atmos. Chem. Phys., 5, 2617-2634, https://doi.org/10.5194/acp-5-2617-2005, 2005. 
Barker, H. W., Korolev, A. V., Hudak, D. R., Strapp, J. W., Strawbridge, K. B., and Wolde, M.: A comparison between CloudSat and aircraft data for a multilayer, mixed phase cloud system during the Canadian CloudSat-CALIPSO Validation Project, J. Geophys. Res.-Atmos., 113, D00A16, https://doi.org/10.1029/2008JD009971, 2008.

Barrie, L. A.: Arctic air pollution: An overview of current knowledge, Atmos. Environ., 20, 643-663, https://doi.org/10.1016/0004-6981(86)90180-0, 1986.

Bigg, E. K.: The Supercooling of Water, P. Phys. Soc. Lond. B, 66, 688, https://doi.org/10.1088/0370-1301/66/8/309, 1953.

Boisvert, L. N. and Stroeve, J. C.: The Arctic is becoming warmer and wetter as revealed by the Atmospheric Infrared Sounder, Geophys. Res. Lett., 42, 4439-4446, https://doi.org/10.1002/2015GL063775, 2015.

Boisvert, L. N., Wu, D. L., Vihma, T., and Susskind, J.: Verification of air/surface humidity differences from AIRS and ERA-Interim in support of turbulent flux estimation in the Arctic, J. Geophys. Res.-Atmos., 120, 2014JD021666, https://doi.org/10.1002/2014JD021666, 2015.

Boucher, O., Randall, D. A., Artaxo, P., Bretherton, C. S., Feingold, G., Forster, P. M., Kerminen, V.-M., Kondo, Y., Liao, H., Lohmann, U., Rasch, P., Satheesh, S. K., Sherwood, S., Stevens, B., and Zhang, X. Y.: Clouds and Aerosols, in Climate Change 2013: The Physical Science Basis. Contribution of Working Group I to the Fifth Assessment Report of the Intergovernmental Panel on Climate Change, edited by: Stocker, T. F., Qin, D., Plattner, G. K., Tignor, M., Allen, S. K., Boschung, J., Nauels, A., Xia, Y., Bex, V., and Midgley, P. M., Cambridge University Press, Cambridge, UK and New York, NY, USA, 2013.

Breider, T. J., Mickley, L. J., Jacob, D. J., Wang, Q., Fisher, J. A., Chang, R. Y.-W., and Alexander, B.: Annual distributions and sources of Arctic aerosol components, aerosol optical depth, and aerosol absorption, J. Geophys. Res.-Atmos., 119, 4107-4124, https://doi.org/10.1002/2013JD020996, 2014.

CALIPSO Science Team: CALIPSO/CALIOP Level 2, Lidar 5km Merged Aerosol and Cloud Layer Data, version 4.10, Hampton, VA, USA: NASA Atmospheric Science Data Center (ASDC), https://doi.org/10.5067/CALIOP/CALIPSO/LID_L2_05kmMLayStandard-V4-10, 2016.

Carrió, G. G., Jiang, H., and Cotton, W. R.: Impact of Aerosol Intrusions on Arctic Boundary Layer Clouds. Part II: Sea Ice Melting Rates, J. Atmos. Sci., 62, 3094-3105, https://doi.org/10.1175/JAS3558.1, 2005.

Cavalieri, D. J., Markus, T., and Comiso, J.: AMSR-E/Aqua Daily L3 $12.5 \mathrm{~km}$ Brightness Temperature, Sea Ice Concentration, \& Snow Depth Polar Grids, Version 3, psn12area_v3.dat. Boulder, Colorado USA, NASA National Snow and Ice Data Center Distributed Active Archive Center, https://doi.org/10.5067/AMSRE/AE_SI12.003, 2014.

Cesana, G. and Chepfer, H.: How well do climate models simulate cloud vertical structure? A comparison between CALIPSOGOCCP satellite observations and CMIP5 models, Geophys. Res. Lett., 39, L20803, https://doi.org/10.1029/2012GL053153, 2012.

Chen, Y.-C., Christensen, M. W., Stephens, G. L., and Seinfeld, J. H.: Satellite-based estimate of global aerosol-cloud radiative forcing by marine warm clouds, Nat. Geosci., 7, 643-646, https://doi.org/10.1038/ngeo2214, 2014.
Chernokulsky, A. and Mokhov, I. I.: Climatology of Total Cloudiness in the Arctic: An Intercomparison of Observations and Reanalyses, Adv. Meteorol., 2012, 542093, https://doi.org/10.1155/2012/542093, 2012.

Chernokulsky, A. V., Esau, I., Bulygina, O. N., Davy, R., Mokhov, I. I., Outten, S., and Semenov, V. A.: Climatology and Interannual Variability of Cloudiness in the Atlantic Arctic from Surface Observations since the Late Nineteenth Century, J. Climate, 30, 2103-2120, https://doi.org/10.1175/JCLI-D-16-0329.1, 2017.

Coopman, Q., Garrett, T. J., Riedi, J., Eckhardt, S., and Stohl, A.: Effects of long-range aerosol transport on the microphysical properties of low-level liquid clouds in the Arctic, Atmos. Chem. Phys., 16, 4661-4674, https://doi.org/10.5194/acp16-4661-2016, 2016.

Coopman, Q., Garrett, T. J., Finch, D. P., and Riedi, J.: High Sensitivity of Arctic Liquid Clouds to Long-Range Anthropogenic Aerosol Transport, Geophys. Res. Lett., 45, 372-381, https://doi.org/10.1002/2017GL075795, 2018.

Creamean, J. M., Maahn, M., de Boer, G., McComiskey, A., Sedlacek, A. J., and Feng, Y.: The influence of local oil exploration and regional wildfires on summer 2015 aerosol over the North Slope of Alaska, Atmos. Chem. Phys., 18, 555-570, https://doi.org/10.5194/acp-18-555-2018, 2018.

Croft, B., Martin, R. V., Leaitch, W. R., Tunved, P., Breider, T. J., D'Andrea, S. D., and Pierce, J. R.: Processes controlling the annual cycle of Arctic aerosol number and size distributions, Atmos. Chem. Phys., 16, 3665-3682, https://doi.org/10.5194/acp16-3665-2016, 2016.

Cziczo, D. J., Froyd, K. D., Gallavardin, S. J., Moehler, O., and Benz, S.: Harald Saathoff and Murphy, D. M.: Deactivation of ice nuclei due to atmospherically relevant surface coatings, Environ. Res. Lett., 4, 044013, https://doi.org/10.1088/17489326/4/4/044013, 2009.

Damoah, R., Spichtinger, N., Forster, C., James, P., Mattis, I., Wandinger, U., Beirle, S., Wagner, T., and Stohl, A.: Around the world in 17 days - hemispheric-scale transport of forest fire smoke from Russia in May 2003, Atmos. Chem. Phys., 4, 13111321, https://doi.org/10.5194/acp-4-1311-2004, 2004.

de Boer, G., Eloranta, E. W., and Shupe, M. D.: Arctic Mixed-Phase Stratiform Cloud Properties from Multiple Years of SurfaceBased Measurements at Two High-Latitude Locations, J. Atmos. Sci., 66, 2874-2887, https://doi.org/10.1175/2009JAS3029.1, 2009.

de Boer, G., Chapman, W., Kay, J. E., Medeiros, B., Shupe, M. D., Vavrus, S., and Walsh, J.: A Characterization of the PresentDay Arctic Atmosphere in CCSM4, J. Climate, 25, 2676-2695, https://doi.org/10.1175/JCLI-D-11-00228.1, 2011.

Devasthale, A., TjernströM, M., Karlsson, K.-G., Thomas, M. A., Jones, C., Sedlar, J., and Omar, A. H.: The vertical distribution of thin features over the Arctic analysed from CALIPSO observations, Part I: Optically thin clouds, Tellus B, 63, 77-85, https://doi.org/10.1111/j.1600-0889.2010.00516.x, 2011a.

Devasthale, A., Tjernström, M., and Omar, A. H.: The vertical distribution of thin features over the Arctic analysed from CALIPSO observations. Part II: Aerosols, Tellus B, 63, 86-95, https://doi.org/10.3402/tellusb.v63i1.16190, 2011 b.

Du, P., Girard, E., Bertram, A. K., and Shupe, M. D.: Modeling of the cloud and radiation processes ob- 
served during SHEBA, Atmos. Res., 101, 911-927, https://doi.org/10.1016/j.atmosres.2011.05.018, 2011.

Earle, M. E., Liu, P. S. K., Strapp, J. W., Zelenyuk, A., Imre, D., McFarquhar, G. M., Shantz, N. C., and Leaitch, W. R.: Factors influencing the microphysics and radiative properties of liquiddominated Arctic clouds: Insight from observations of aerosol and clouds during ISDAC, J. Geophys. Res., 116, D00T09, https://doi.org/10.1029/2011JD015887, 2011.

Eastman, R. and Warren, S. G.: Interannual Variations of Arctic Cloud Types in Relation to Sea Ice, J. Climate, 23, 4216-4232, https://doi.org/10.1175/2010JCLI3492.1, 2010.

Eckhardt, S., Quennehen, B., Olivié, D. J. L., Berntsen, T. K., Cherian, R., Christensen, J. H., Collins, W., Crepinsek, S., Daskalakis, N., Flanner, M., Herber, A., Heyes, C., Hodnebrog, Ø., Huang, L., Kanakidou, M., Klimont, Z., Langner, J., Law, K. S., Lund, M. T., Mahmood, R., Massling, A., Myriokefalitakis, S., Nielsen, I. E., Nøjgaard, J. K., Quaas, J., Quinn, P. K., Raut, J.-C., Rumbold, S. T., Schulz, M., Sharma, S., Skeie, R. B., Skov, H., Uttal, T., von Salzen, K., and Stohl, A.: Current model capabilities for simulating black carbon and sulfate concentrations in the Arctic atmosphere: a multi-model evaluation using a comprehensive measurement data set, Atmos. Chem. Phys., 15, 9413-9433, https://doi.org/10.5194/acp-15-9413-2015, 2015.

Engström, A. and Ekman, A. M. L.: Impact of meteorological factors on the correlation between aerosol optical depth and cloud fraction, Geophys. Res. Lett., 37, L18814, https://doi.org/10.1029/2010GL044361, 2010.

Fan, J., Ovtchinnikov, M., Comstock, J. M., McFarlane, S. A., and Khain, A.: Ice formation in Arctic mixed-phase clouds: Insights from a 3-D cloud-resolving model with size-resolved aerosol and cloud microphysics, J. Geophys. Res.-Atmos., 114, D04205, https://doi.org/10.1029/2008JD010782, 2009.

Fan, J., Wang, Y., Rosenfeld, D., and Liu, X.: Review of AerosolCloud Interactions: Mechanisms, Significance, and Challenges, J. Atmos, Sci., 73, 4221-4252, https://doi.org/10.1175/JAS-D16-0037.1, 2016.

Forster, C., Wandinger, U., Wotawa, G., James, P., Mattis, I., Althausen, D., Simmonds, P., O’Doherty, S., Jennings, S. G., Kleefeld, C., Schneider, J., Trickl, T., Kreipl, S., Jäger, H., and Stohl, A.: Transport of boreal forest fire emissions from Canada to Europe, J. Geophys. Res.-Atmos., 106, 22887-22906, https://doi.org/10.1029/2001JD900115, 2001.

Fu, S. and Xue, H.: The Effect of Ice Nuclei Efficiency on Arctic Mixed-Phase Clouds from Large-Eddy Simulations, J. Atmos. Sci., 74, 3901-3913, https://doi.org/10.1175/JAS-D-17-0112.1, 2017.

Garrett, T. J., Zhao, C., Dong, X., Mace, G. G., and Hobbs, P. V.: Effects of varying aerosol regimes on lowlevel Arctic stratus, Geophys. Res. Lett., 31, L17105, https://doi.org/10.1029/2004GL019928, 2004.

Gettelman, A.: Putting the clouds back in aerosol-cloud interactions, Atmos. Chem. Phys., 15, 12397-12411, https://doi.org/10.5194/acp-15-12397-2015, 2015.

Giglio, L., Randerson, J. T., and Werf, G. R.: Analysis of daily, monthly, and annual burned area using the fourthgeneration global fire emissions database (GFED4), J. Geophys. Res.-Biogeo., 118, 317-328, https://doi.org/10.1002/jgrg.20042, 2013.
Girard, E., Blanchet, J.-P., and Dubois, Y.: Effects of arctic sulphuric acid aerosols on wintertime lowlevel atmospheric ice crystals, humidity and temperature at Alert, Nunavut, Atmos. Res., 73, 131-148, https://doi.org/10.1016/j.atmosres.2004.08.002, 2005.

Girard, E., Dueymes, G., Du, P., and Bertram, A. K.: Assessment of the effects of acid-coated ice nuclei on the Arctic cloud microstructure, atmospheric dehydration, radiation and temperature during winter, Int. J. Climatol., 33, 599-614, https://doi.org/10.1002/joc.3454, 2013.

Groot Zwaaftink, C. D., Grythe, H., Skov, H., and Stohl, A.: Substantial contribution of northern high-latitude sources to mineral dust in the Arctic, J. Geophys. Res.-Atmos., 121, 13678-13697, https://doi.org/10.1002/2016JD025482, 2016.

Gryspeerdt, E., Quaas, J., and Bellouin, N.: Constraining the aerosol influence on cloud fraction, J. Geophys. Res.-Atmos., 121, 35663583, https://doi.org/10.1002/2015JD023744, 2016.

Hastie, T. J. and Tibshirani, R. J.: Generalized Additive Models, Chapman and Hall, London, 1990.

Henderson, D. S., L'Ecuyer, T., Stephens, G., Partain, P., and Sekiguchi, M.: A Multisensor Perspective on the Radiative Impacts of Clouds and Aerosols, J. Appl. Meteorol. Clim., 52, 853871, https://doi.org/10.1175/JAMC-D-12-025.1, 2012.

Heymsfield, A. J., Krämer, M., Luebke, A., Brown, P., Cziczo, D. J., Franklin, C., Lawson, P., Lohmann, U., McFarquhar, G., Ulanowski, Z., and Van Tricht, K.: Cirrus Clouds, Meteorol. Monogr., 58, 2.1-2.26, https://doi.org/10.1175/AMSMONOGRAPHS-D-16-0010.1, 2016.

Hudak, D., Rodriguez, P., and Donaldson, N.: Validation of the CloudSat precipitation occurrence algorithm using the Canadian C band radar network, J. Geophys. Res.-Atmos., 113, D00A07, https://doi.org/10.1029/2008JD009992, 2008.

Jakobson, E., Vihma, T., Palo, T., Jakobson, L., Keernik, H., and Jaagus, J.: Validation of atmospheric reanalyses over the central Arctic Ocean, Geophys. Res. Lett., 39, L10802, https://doi.org/10.1029/2012GL051591, 2012.

Jørgensen, B.: The Theory of Dispersion Models, Chapman and Hall, London, UK, 1997.

Jouan, C., Pelon, J., Girard, E., Ancellet, G., Blanchet, J. P., and Delanoë, J.: On the relationship between Arctic ice clouds and polluted air masses over the North Slope of Alaska in April 2008, Atmos. Chem. Phys., 14, 1205-1224, https://doi.org/10.5194/acp-14-1205-2014, 2014

Kanji, Z. A., Ladino, L. A., Wex, H., Boose, Y., BurkertKohn, M., Cziczo, D. J., and Krämer, M.: Overview of Ice Nucleating Particles, Meteorol. Monogr., 58, 1.1-1.33, https://doi.org/10.1175/AMSMONOGRAPHS-D-16-0006.1, 2017.

Kay, J. E. and L'Ecuyer, T.: Observational constraints on Arctic Ocean clouds and radiative fluxes during the early 21st century, J. Geophys. Res.-Atmos., 118, 7219-7236, https://doi.org/10.1002/jgrd.50489, 2013.

Kay, J. E., Raeder, K., Gettelman, A., and Anderson, J.: The Boundary Layer Response to Recent Arctic Sea Ice Loss and Implications for High-Latitude Climate Feedbacks, J. Climate, 24, 428447, https://doi.org/10.1175/2010JCLI3651.1, 2010.

Lance, S., Shupe, M. D., Feingold, G., Brock, C. A., Cozic, J., Holloway, J. S., Moore, R. H., Nenes, A., Schwarz, J. P., Spackman, 
J. R., Froyd, K. D., Murphy, D. M., Brioude, J., Cooper, O. R., Stohl, A., and Burkhart, J. F.: Cloud condensation nuclei as a modulator of ice processes in Arctic mixed-phase clouds, Atmos. Chem. Phys., 11, 8003-8015, https://doi.org/10.5194/acp11-8003-2011, 2011.

L'Ecuyer, T. S., Wood, N. B., Haladay, T., Stephens, G. L., and Stackhouse, P. W.: Impact of clouds on atmospheric heating based on the R04 CloudSat fluxes and heating rates data set, J. Geophys. Res.-Atmos., 113, D00A15, https://doi.org/10.1029/2008JD009951, 2008.

Lindsey, D. T. and Fromm, M.: Evidence of the cloud lifetime effect from wildfire-induced thunderstorms, Geophys. Res. Lett., 35, L22809, https://doi.org/10.1029/2008GL035680, 2008.

Liu, X., Xie, S., Boyle, J., Klein, S. A., Shi, X., Wang, Z., Lin, W., Ghan, S. J., Earle, M., Liu, P. S. K., and Zelenyuk, A.: Testing cloud microphysics parameterizations in NCAR CAM5 with ISDAC and M-PACE observations, J. Geophys. Res.-Atmos., 116, D00T11, https://doi.org/10.1029/2011JD015889, 2011.

Liu, Y., Shupe, M. D., Wang, Z., and Mace, G.: Cloud vertical distribution from combined surface and space radar-lidar observations at two Arctic atmospheric observatories, Atmos. Chem. Phys., 17, 5973-5989, https://doi.org/10.5194/acp-175973-2017, 2017.

Lohmann, U.: A glaciation indirect aerosol effect caused by soot aerosols, Geophys. Res. Lett., 29, 1052, https://doi.org/10.1029/2001GL014357, 2002.

Lohmann, U. and Feichter, J.: Global indirect aerosol effects: a review, Atmos. Chem. Phys., 5, 715-737, https://doi.org/10.5194/acp-5-715-2005, 2005.

Lubin, D. and Vogelmann, A. M.: A climatologically significant aerosol longwave indirect effect in the Arctic, Nature, 439, 453456, https://doi.org/10.1038/nature04449, 2006.

Maahn, M., de Boer, G., Creamean, J. M., Feingold, G., McFarquhar, G. M., Wu, W., and Mei, F.: The observed influence of local anthropogenic pollution on northern Alaskan cloud properties, Atmos. Chem. Phys., 17, 14709-14726, https://doi.org/10.5194/acp-17-14709-2017, 2017.

Mace, G. G. and Zhang, Q.: The CloudSat radar-lidar geometrical profile product (RL-GeoProf): Updates, improvements, and selected results, J. Geophys. Res.-Atmos., 119, 2013JD021374, https://doi.org/10.1002/2013JD021374, 2014.

Mace, G. G., Zhang, Q., Vaughan, M., Marchand, R., Stephens, G., Trepte, C., and Winker, D.: A description of hydrometeor layer occurrence statistics derived from the first year of merged Cloudsat and CALIPSO data, J. Geophys. Res.-Atmos., 114, D00A26, https://doi.org/10.1029/2007JD009755, 2009.

Meier, W., Fetterer, F., Savoie, M., Mallory, S., Duerr, R., and Stroeve, J. C.: NOAA/NSIDC Climate Data Record of Passive Microwave Sea Ice Concentration, Version 2. [G02202], NSIDC: National Snow and Ice Data Center, Boulder, Colorado, USA, https://doi.org/10.7265/N55M63M1, 2013.

Morrison, H., Pinto, J. O., Curry, J. A., and McFarquhar, G. M.: Sensitivity of modeled arctic mixed-phase stratocumulus to cloud condensation and ice nuclei over regionally varying surface conditions, J. Geophys. Res.-Atmos., 113, D05203, https://doi.org/10.1029/2007JD008729, 2008.

Morrison, H., Zuidema, P., Ackerman, A. S., Avramov, A., Boer, G. de, Fan, J., Fridlind, A. M., Hashino, T., Harrington, J. Y., Luo, Y., Ovchinnikov, M., and Shipway, B.: Intercomparison of cloud model simulations of Arctic mixed-phase boundary layer clouds observed during SHEBA/FIRE-ACE, J. Adv. Model. Earth Syst., 3, M06003, https://doi.org/10.1029/2011MS000066, 2011.

Morrison, H., de Boer, G., Feingold, G., Harrington, J., Shupe, M. D., and Sulia, K.: Resilience of persistent Arctic mixed-phase clouds, Nat. Geosci., 5, 11-17, https://doi.org/10.1038/ngeo1332, 2012.

Nishant, N. and Sherwood, S. C.: A cloud-resolving model study of aerosol-cloud correlation in a pristine maritime environment, Geophys. Res. Lett., 44, 5774-5781, https://doi.org/10.1002/2017GL073267, 2017.

Noh, Y.-J., Seaman, C. J., Vonder Haar, T. H., Hudak, D. R., and Rodriguez, P.: Comparisons and analyses of aircraft and satellite observations for wintertime mixed-phase clouds, J. Geophys. Res.Atmos., 116, D18207, https://doi.org/10.1029/2010JD015420, 2011.

Norgren, M. S., de Boer, G., and Shupe, M. D.: Observed aerosol suppression of cloud ice in low-level Arctic mixed-phase clouds, Atmos. Chem. Phys., 18, 13345-13361, https://doi.org/10.5194/acp-18-13345-2018, 2018.

Oreopoulos, L., Cho, N., and Lee, D.: Using MODIS cloud regimes to sort diagnostic signals of aerosol-cloud-precipitation interactions, J. Geophys. Res.-Atmos., 122, 5416-5440, https://doi.org/10.1002/2016JD026120, 2017.

Ovchinnikov, M., Ackerman, A. S., Avramov, A., Cheng, A., Fan, J., Fridlind, A. M., Ghan, S., Harrington, J., Hoose, C., Korolev, A., McFarquhar, G. M., Morrison, H., Paukert, M., Savre, J., Shipway, B. J., Shupe, M. D., Solomon, A., and Sulia, K.: Intercomparison of large-eddy simulations of Arctic mixed-phase clouds: Importance of ice size distribution assumptions, J. Adv. Model. Earth Syst., 6, 223-248, https://doi.org/10.1002/2013MS000282, 2014.

Paris, J.-D., Stohl, A., Nédélec, P., Arshinov, M. Yu., Panchenko, M. V., Shmargunov, V. P., Law, K. S., Belan, B. D., and Ciais, P.: Wildfire smoke in the Siberian Arctic in summer: source characterization and plume evolution from airborne measurements, Atmos. Chem. Phys., 9, 9315-9327, https://doi.org/10.5194/acp9-9315-2009, 2009.

Peng, G., Meier, W. N., Scott, D. J., and Savoie, M. H.: A long-term and reproducible passive microwave sea ice concentration data record for climate studies and monitoring, Earth Syst. Sci. Data, 5, 311-318, https://doi.org/10.5194/essd-5-311-2013, 2013.

Pinto, J. O.: Autumnal Mixed-Phase Cloudy Boundary Layers in the Arctic, J. Atmos. Sci., 55, 2016-2038, https://doi.org/10.1175/15200469(1998)055<2016:AMPCBL>2.0.CO;2, 1998.

Qian, Y., Long, C. N., Wang, H., Comstock, J. M., McFarlane, S. A., and Xie, S.: Evaluation of cloud fraction and its radiative effect simulated by IPCC AR4 global models against ARM surface observations, Atmos. Chem. Phys., 12, 1785-1810, https://doi.org/10.5194/acp-12-1785-2012, 2012.

Quinn, P. K., Shaw, G., Andrews, E., Dutton, E. G., Ruoho-Airola, T., and Gong, S. L.: Arctic haze: current trends and knowledge gaps, Tellus B, 59, 99-114, https://doi.org/10.1111/j.16000889.2006.00236.x, 2007.

Russell, P. B., Kacenelenbogen, M., Livingston, J. M., Hasekamp, O. P., Burton, S. P., Schuster, G. L., Johnson, M. S., Knobelspiesse, K. D., Redemann, J., Ramachandran, S., and Holben, B.: A multiparameter aerosol classification 
method and its application to retrievals from spaceborne polarimetry, J. Geophys. Res.-Atmos., 119, 2013JD021411, https://doi.org/10.1002/2013JD021411, 2014.

Saleeby, S. M., Cotton, W. R., Lowenthal, D., Borys, R. D., and Wetzel, M. A.: Influence of Cloud Condensation Nuclei on Orographic Snowfall, J. Appl. Meteorol. Clim., 48, 903-922, https://doi.org/10.1175/2008JAMC1989.1, 2009.

Samset, B. H., Stjern, C. W., Andrews, E., Kahn, R. A., Myhre, G., Schulz, M., and Schuster, G. L.: Aerosol Absorption: Progress Towards Global and Regional Constraints, Curr. Clim. Change Rep., 1-19, https://doi.org/10.1007/s40641-018-0091-4, 2018.

Serreze, M. C. and Barry, R. G.: The Arctic Climate System, Camb. Core, https://doi.org/10.1017/CBO9780511535888, 2005.

Sodemann, H., Pommier, M., Arnold, S. R., Monks, S. A., Stebel, K., Burkhart, J. F., Hair, J. W., Diskin, G. S., Clerbaux, C., Coheur, P.-F., Hurtmans, D., Schlager, H., Blechschmidt, A.M., Kristjánsson, J. E., and Stohl, A.: Episodes of crosspolar transport in the Arctic troposphere during July 2008 as seen from models, satellite, and aircraft observations, Atmos. Chem. Phys., 11, 3631-3651, https://doi.org/10.5194/acp-113631-2011, 2011.

Södergren, A. H., McDonald, A. J., and Bodeker, G. E.: An energy balance model exploration of the impacts of interactions between surface albedo, cloud cover and water vapor on polar amplification, Clim. Dynam., 1-20, https://doi.org/10.1007/s00382-0173974-5, 2017.

Sokal, R. R. and Rohlf, F. J.: Biometry: The Principles and Practice of Statistics in Biological Research, 3rd ed., Macmillan, 1995.

Solomon, A., Feingold, G., and Shupe, M. D.: The role of ice nuclei recycling in the maintenance of cloud ice in Arctic mixedphase stratocumulus, Atmos. Chem. Phys., 15, 10631-10643, https://doi.org/10.5194/acp-15-10631-2015, 2015.

Stanfield, R. E., Dong, X., Xi, B., Kennedy, A., Del Genio, A. D., Minnis, P., and Jiang, J. H.: Assessment of NASA GISS CMIP5 and Post-CMIP5 Simulated Clouds and TOA Radiation Budgets Using Satellite Observations. Part I: Cloud Fraction and Properties, J. Climate, 27, 4189-4208, https://doi.org/10.1175/JCLI-D13-00558.1, 2014.

Stevens, R. G., Loewe, K., Dearden, C., Dimitrelos, A., Possner, A., Eirund, G. K., Raatikainen, T., Hill, A. A., Shipway, B. J., Wilkinson, J., Romakkaniemi, S., Tonttila, J., Laaksonen, A., Korhonen, H., Connolly, P., Lohmann, U., Hoose, C., Ekman, A. M. L., Carslaw, K. S., and Field, P. R.: A model intercomparison of CCN-limited tenuous clouds in the high Arctic, Atmos. Chem. Phys., 18, 11041-11071, https://doi.org/10.5194/acp-18-110412018, 2018.

Stohl, A., Hittenberger, M., and Wotawa, G.: Validation of the lagrangian particle dispersion model FLEXPART against largescale tracer experiment data, Atmos. Environ., 32, 4245-4264, https://doi.org/10.1016/S1352-2310(98)00184-8, 1998.

Stohl, A., Eckhardt, S., Forster, C., James, P., and Spichtinger, N.: On the pathways and timescales of intercontinental air pollution transport, J. Geophys. Res.-Atmos., 107, 4684, https://doi.org/10.1029/2001JD001396, 2002.

Stohl, A., Forster, C., Eckhardt, S., Spichtinger, N., Huntrieser, H., Heland, J., Schlager, H., Wilhelm, S., Arnold, F., and Cooper, O.: A backward modeling study of intercontinental pollution transport using aircraft measurements, J. Geophys. Res.-Atmos., 108, 4370, https://doi.org/10.1029/2002JD002862, 2003.
Stohl, A., Forster, C., Frank, A., Seibert, P., and Wotawa, G.: Technical note: The Lagrangian particle dispersion model FLEXPART version 6.2, Atmos. Chem. Phys., 5, 2461-2474, https://doi.org/10.5194/acp-5-2461-2005, 2005.

Stohl, A., Aamaas, B., Amann, M., Baker, L. H., Bellouin, N., Berntsen, T. K., Boucher, O., Cherian, R., Collins, W., Daskalakis, N., Dusinska, M., Eckhardt, S., Fuglestvedt, J. S., Harju, M., Heyes, C., Hodnebrog, Ø., Hao, J., Im, U., Kanakidou, M., Klimont, Z., Kupiainen, K., Law, K. S., Lund, M. T., Maas, R., MacIntosh, C. R., Myhre, G., Myriokefalitakis, S., Olivié, D., Quaas, J., Quennehen, B., Raut, J.-C., Rumbold, S. T., Samset, B. H., Schulz, M., Seland, Ø., Shine, K. P., Skeie, R. B., Wang, S., Yttri, K. E., and Zhu, T.: Evaluating the climate and air quality impacts of short-lived pollutants, Atmos. Chem. Phys., 15, 10529-10566, https://doi.org/10.5194/acp-15-105292015, 2015.

Stohl, A., Andrews, E., Burkhart, J. F., Forster, C., Herber, A., Hoch, S. W., Kowal, D., Lunder, C., Mefford, T., Ogren, J. A., Sharma, S., Spichtinger, N., Stebel, K., Stone, R., Ström, J., Tørseth, K., Wehrli, C., and Yttri, K. E.: Pan-Arctic enhancements of light absorbing aerosol concentrations due to North American boreal forest fires during summer 2004, J. Geophys. Res., 111, D22214, https://doi.org/10.1029/2006JD007216, 2006.

Susskind, J., Blaisdell, J. M., and Iredell, L.: Improved methodology for surface and atmospheric soundings, error estimates, and quality control procedures: the atmospheric infrared sounder science team version-6 retrieval algorithm, J. Appl. Remote Sens., 8, 084994, https://doi.org/10.1117/1.JRS.8.084994, 2014.

Tan, I., Storelvmo, T., and Choi, Y.-S.: Spaceborne lidar observations of the ice-nucleating potential of dust, polluted dust, and smoke aerosols in mixed-phase clouds, J. Geophys. Res.-Atmos., 119, 6653-6665, https://doi.org/10.1002/2013JD021333, 2014.

Tietze, K., Riedi, J., Stohl, A., and Garrett, T. J.: Space-based evaluation of interactions between aerosols and low-level Arctic clouds during the Spring and Summer of 2008, Atmos. Chem. Phys., 11, 3359-3373, https://doi.org/10.5194/acp-113359-2011, 2011.

Van Tricht, K., Lhermitte, S., Lenaerts, J. T. M., Gorodetskaya, I. V., L'Ecuyer, T. S., Noël, B., van den Broeke, M. R., Turner, D. D., and van Lipzig, N. P. M.: Clouds enhance Greenland ice sheet meltwater runoff, Nat. Commun., 7, 10266, https://doi.org/10.1038/ncomms10266, 2016.

Vergara-Temprado, J., Holden, M. A., Orton, T. R., O'Sullivan, D., Umo, N. S., Browse, J., Reddington, C., Baeza-Romero, M. T., Jones, J. M., Lea-Langton, A., Williams, A., Carslaw, K. S., and Murray, B. J.: Is Black Carbon an Unimportant Ice-Nucleating Particle in Mixed-Phase Clouds?, J. Geophys. Res.-Atmos., 123, 4273-4283, https://doi.org/10.1002/2017JD027831, 2018.

Wang, Z.: B-CLDCLASS-LIDAR Interface Control Document, available at: http://cswww.cira.colostate.edu/icd_pdf.php?avid= 36\&pvids=12 (last access: 11 August 2016), 2013.

Xie, Y., Li, Z., Li, L., Wagener, R., Abboud, I., Li, K., Li, D., Zhang, Y., Chen, X., and Xu, H.: Aerosol optical, microphysical, chemical and radiative properties of high aerosol load cases over the Arctic based on AERONET measurements, Sci. Rep., 8, 9376, https://doi.org/10.1038/s41598-018-27744-z, 2018.

Zamora, L. M., Kahn, R. A., Cubison, M. J., Diskin, G. S., Jimenez, J. L., Kondo, Y., McFarquhar, G. M., Nenes, A., Thornhill, K. L., Wisthaler, A., Zelenyuk, A., and Ziemba, L. D.: Aircraft- 
measured indirect cloud effects from biomass burning smoke in the Arctic and subarctic, Atmos. Chem. Phys., 16, 715-738, https://doi.org/10.5194/acp-16-715-2016, 2016.

Zamora, L. M., Kahn, R. A., Eckhardt, S., McComiskey, A., Sawamura, P., Moore, R., and Stohl, A.: Aerosol indirect effects on the nighttime Arctic Ocean surface from thin, predominantly liquid clouds, Atmos. Chem. Phys., 17, 7311-7332, https://doi.org/10.5194/acp-17-7311-2017, 2017.

Zhao, B., Liou, K.-N., Gu, Y., Jiang, J. H., Li, Q., Fu, R., Huang, L., Liu, X., Shi, X., Su, H., and He, C.: Impact of aerosols on ice crystal size, Atmos. Chem. Phys., 18, 1065-1078, https://doi.org/10.5194/acp-18-1065-2018, 2018.
Zhao, C. and Garrett, T. J.: Effects of Arctic haze on surface cloud radiative forcing, Geophys. Res. Lett., 42, 557-564, https://doi.org/10.1002/2014GL062015, 2015.

Zib, B. J., Dong, X., Xi, B., and Kennedy, A.: Evaluation and Intercomparison of Cloud Fraction and Radiative Fluxes in Recent Reanalyses over the Arctic Using BSRN Surface Observations, J. Climate, 25, 2291-2305, https://doi.org/10.1175/JCLI-D-11$00147.1,2012$. 